\title{
الأداة بين النحويين والمناطقة
}

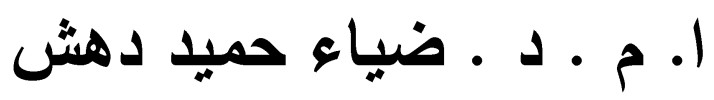 \\ كليَّة الآداب / جامعة بغد اد}

الحمد لله ربّ العالمين و الصلاة والسلام على خاتم النبيين وعلى آله الطيبين

الطاهرين وصحبه المنتجبين الز اكين ـ وبعد ....

فقد تمتع الفكر الاسلامي بالإحاطة بجميع العلوم الموروثة منها والدخيلة ، ليندمج

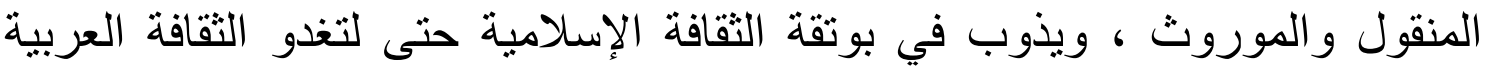

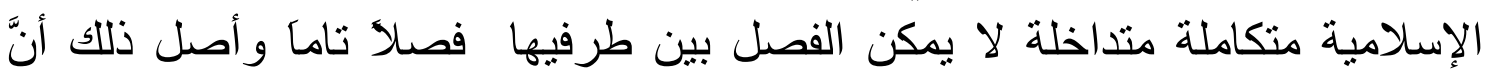

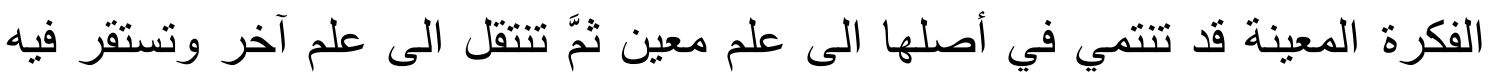

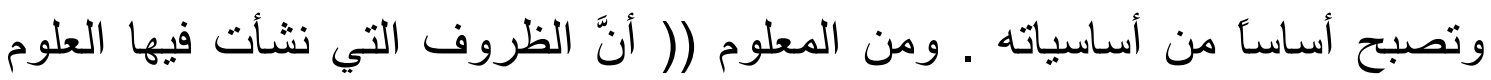

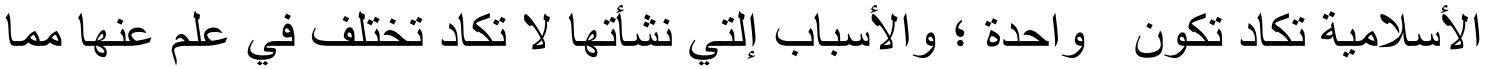

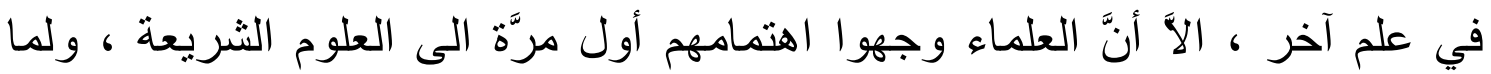

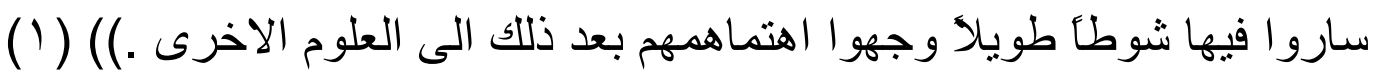

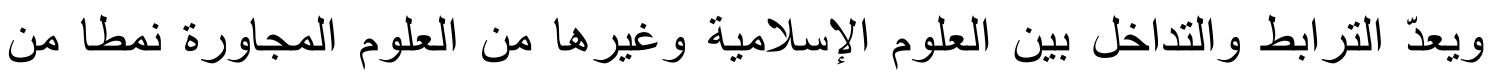

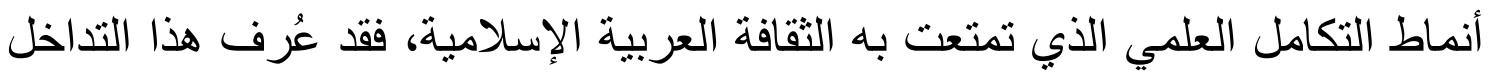

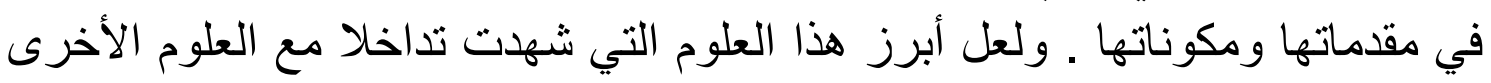

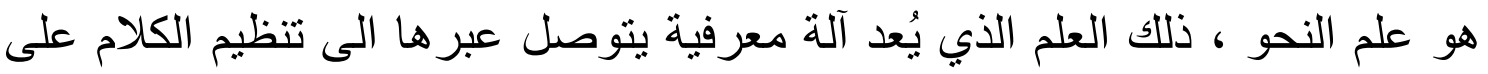
وفق قو اعد و أصول منهجية استخلصت من استقر اء كلام العرب .

ويبدو أنَّ العلاقة التي أنا بصدد نتخيصها إنَّما تتحدد بالعلاقة بين النظم المعرفية

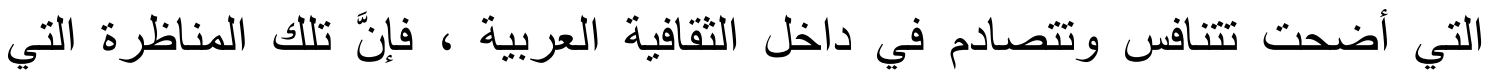

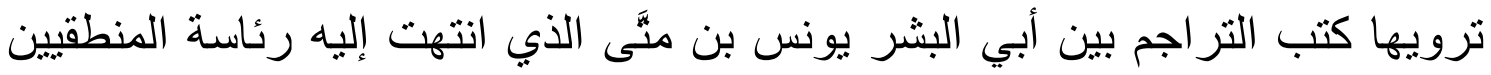

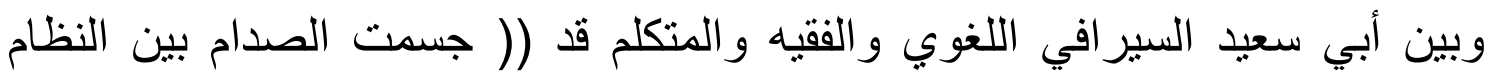

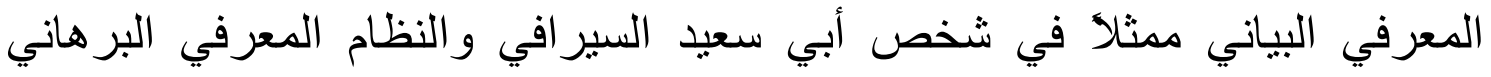
مثنلا في شخص أبي بشر)(ان) (r).

ومما لاريب فيه أنَّ لكل علم مصطلحاته و الفاظه الخاصة به المتعارف عليها

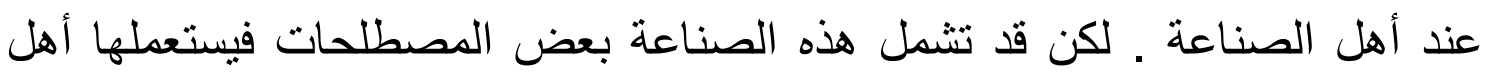


الصناعة الأخرى وإن اختلفت دلالتها عندهم يقول الفار ابي : (( وينبغي أن نعلم أنَّ أصناف الألفاظ التي تشتمل عليها الصناعة النحوية يوجد منها ما يستعمله الجمهور

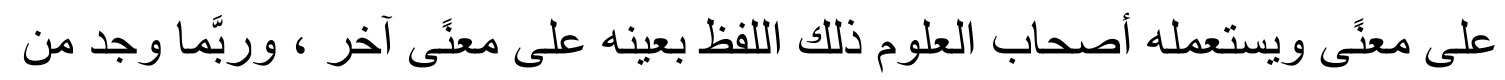

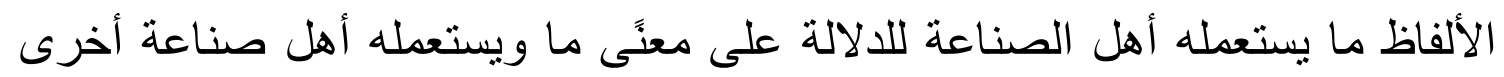

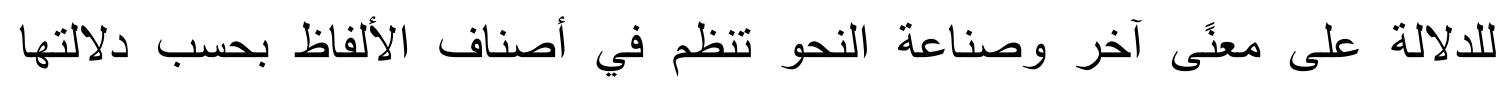

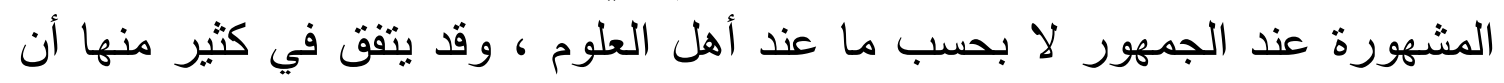

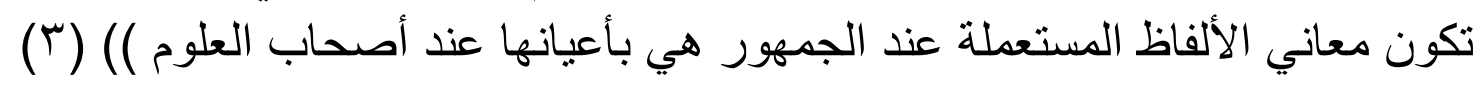
فالمصطلحات النحوية المنطقية بهذا الثكل تلتقي مع المصطلحات النحوية

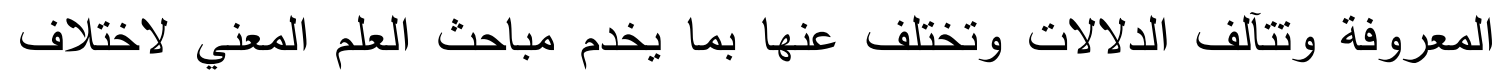

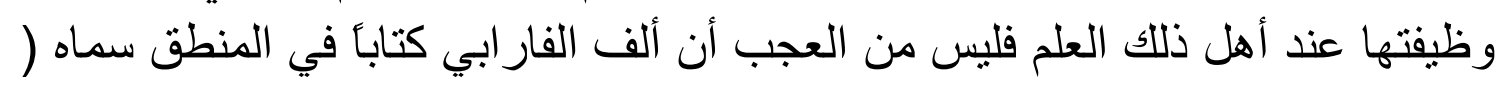

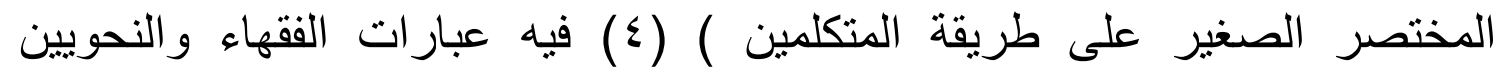
و المتكلمين و اصطلاحاتهم .

مع هذا فإنَّ لكل علم مصطلحاته ودلالاته التي تختلف لاختلاف مشاربها وطرقها

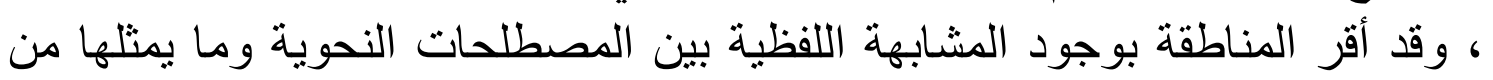

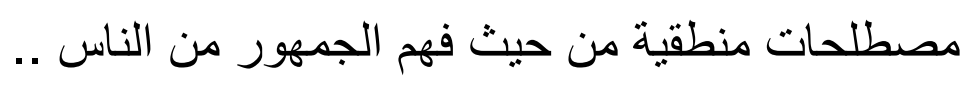
سأحاول في بحثي هذا تسليط الضوء على مصطلح ( الأداة ) فهذا المصطلح كثير

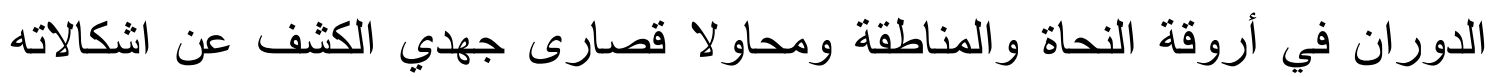

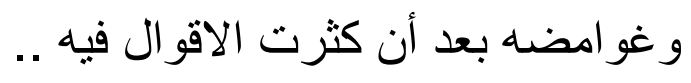

\section{الاداة لغة}

الأداة في اللغة هي الحرفة و (( لكل ذي حرفة أداة )) (0) والجمع أدوات وأداه

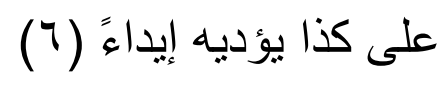

فالأداة هي الآلة المستعملة في الحرفة أو آلة الحرب أي السلاح (V) .

الأداة اصطلاحاً

يبدو أنَّ النحويين لم يتفقوا على معنَى الأداة الاصطلاحي . على أنَّنا لانعدم

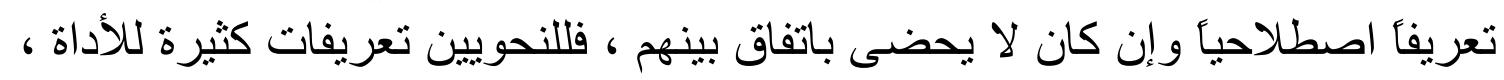

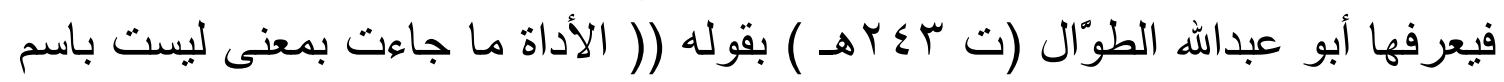

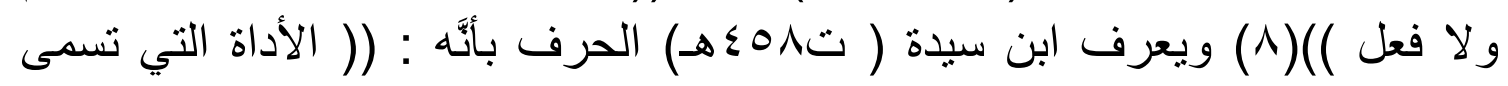


الرابط لأنَّها تربط الاسم والفعل بالفعل ك (عن و على ونحوها ))(9) (9) ومن هذين

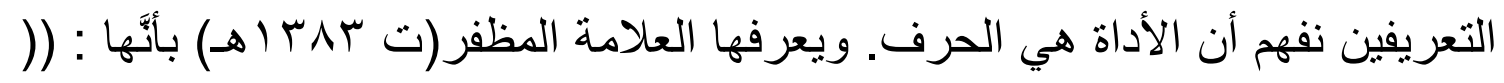

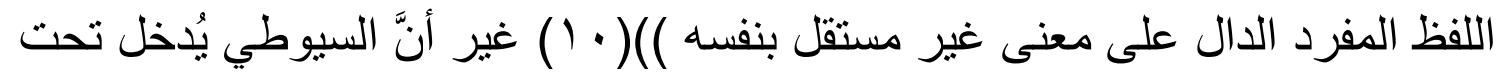

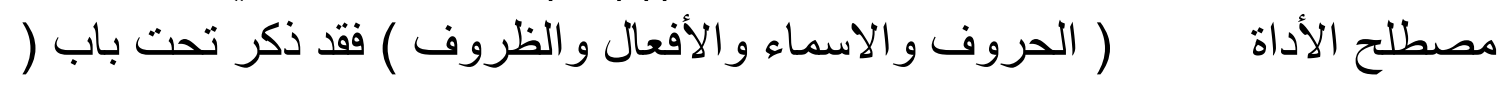

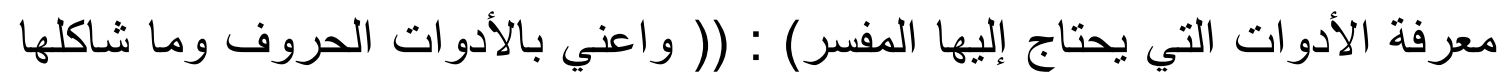

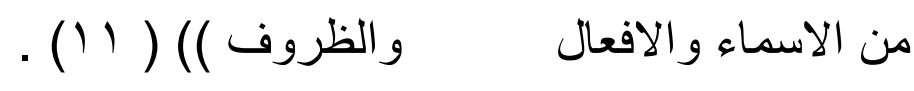

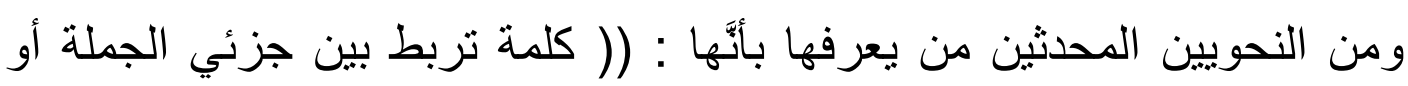

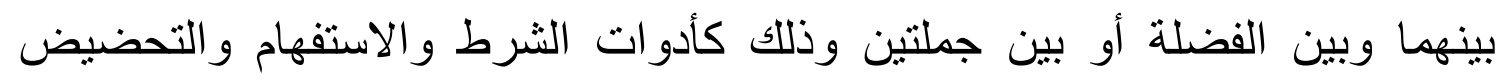

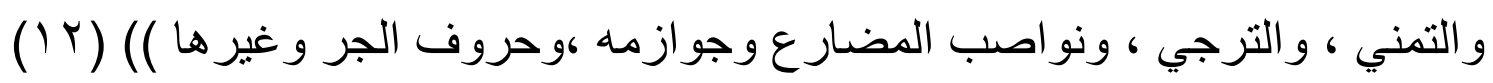

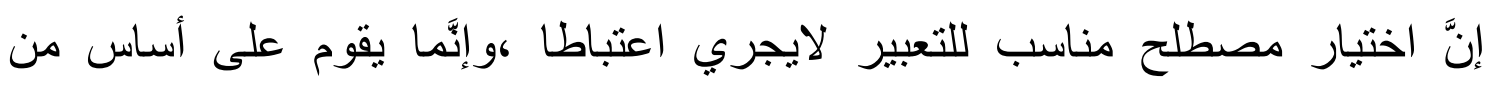

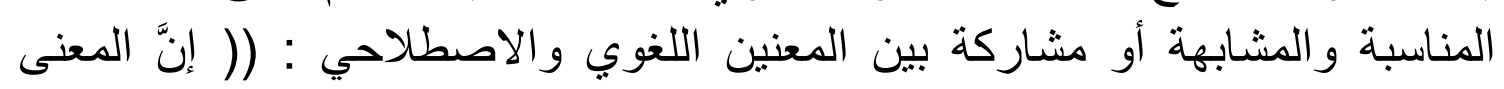

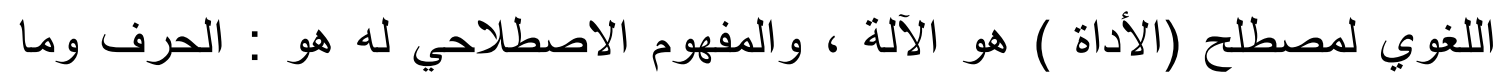

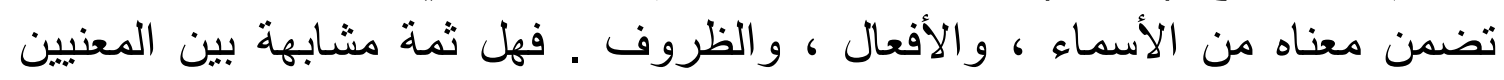

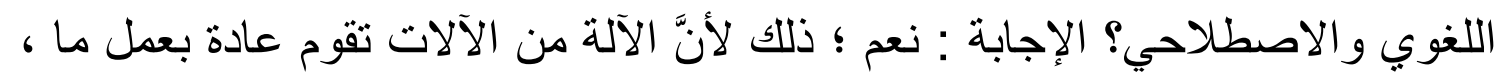

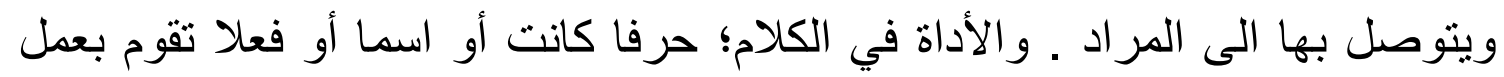

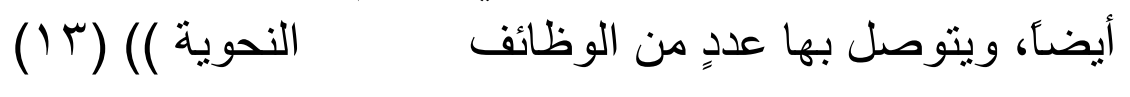

\section{مفهوم الأداء عند النحاة والمناطقة}

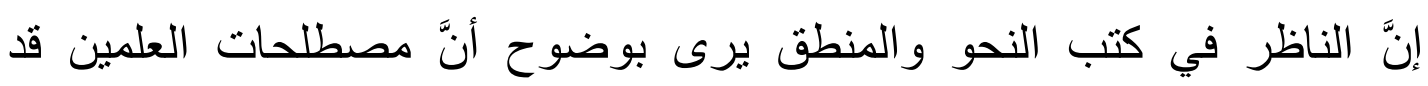

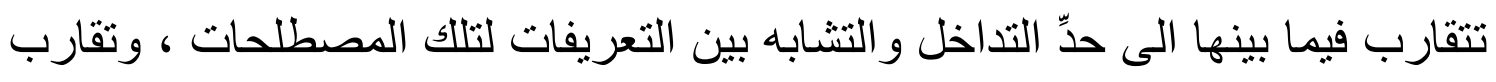

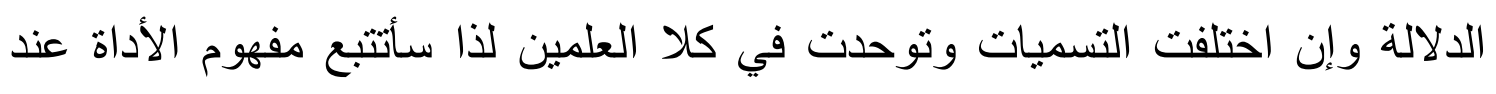
النحويين و المناطقة .

\section{مفهوم الأداة عند النحويين القدماء}

ذكرت في السطور السابقة أنَّ مفهوم مصطلح معين إنّما يجري وفق معايير

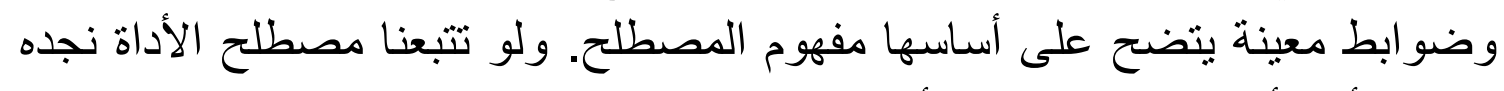

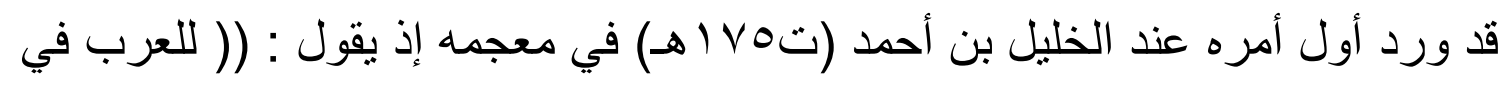

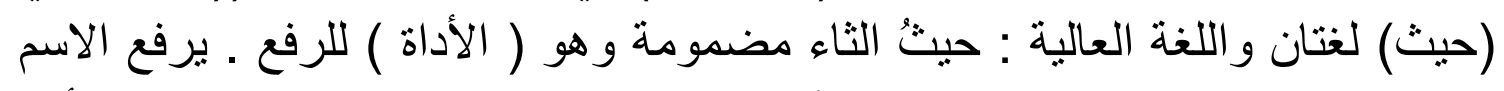

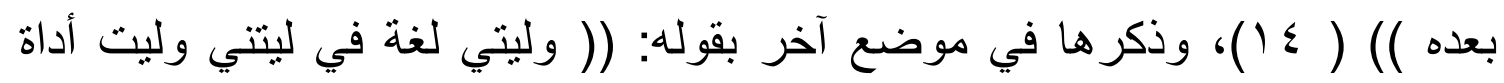


النصب وهو التمني )) (10) فالأداة عند الخليل من العوامل وهي تعمل الرفع و النصب.

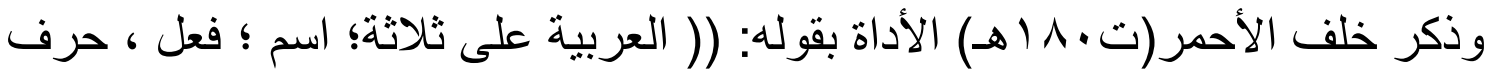

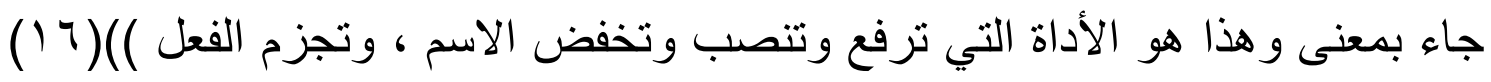

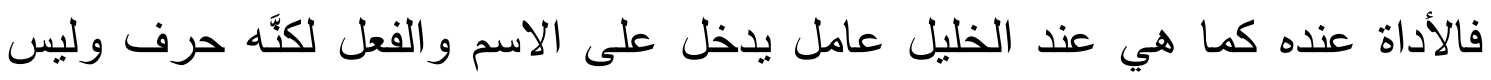

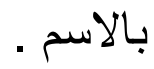

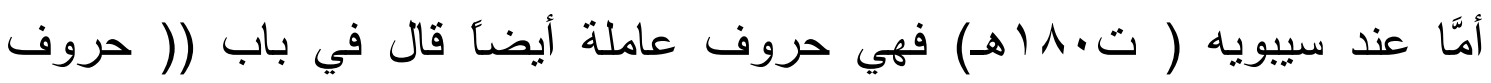

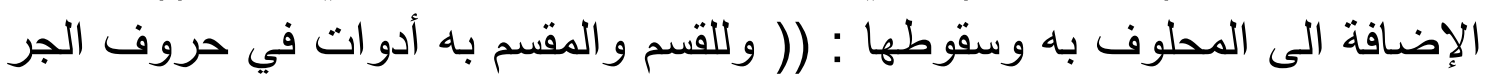

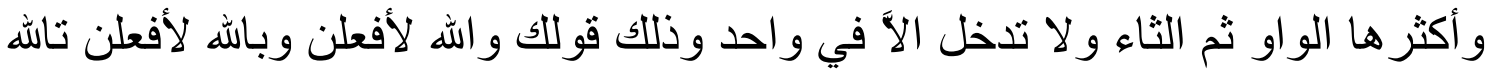

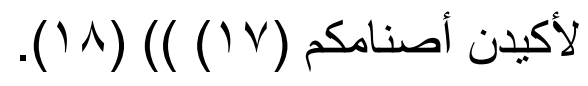

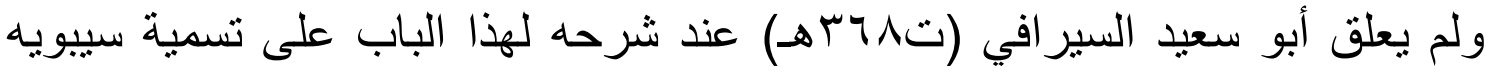

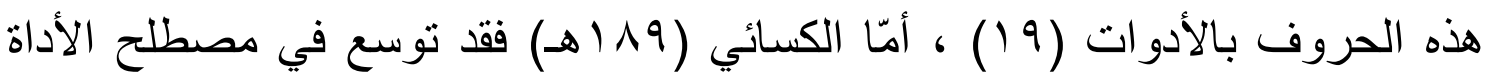

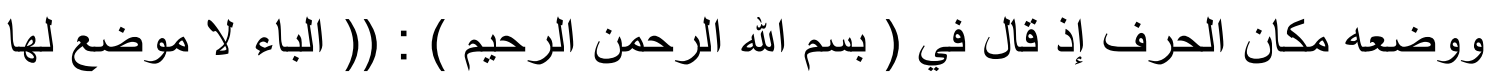

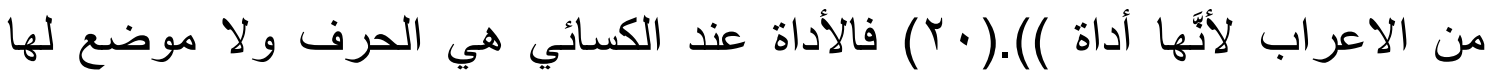
والأمر عينه عند الفراء (تV.Vه) فقد ذكر ذللك عند تفسيره لقوله تعالى :

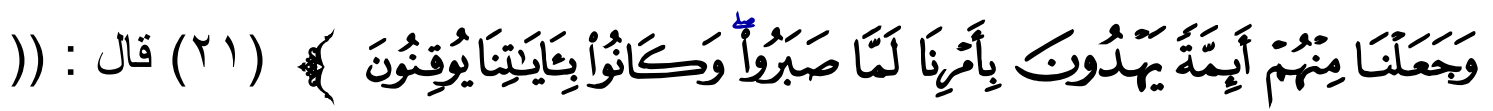
القرَّاء جميعاً على (لمَّا صبروا) بتشديد الميم ونصب اللام ـ و هي قراءة عبد الله (بما

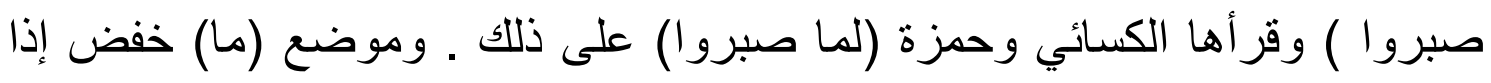

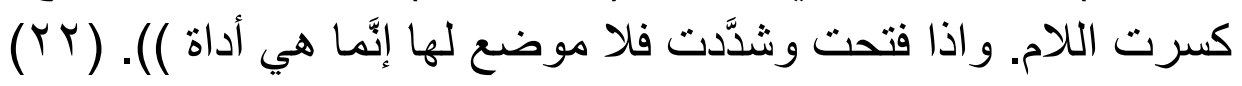

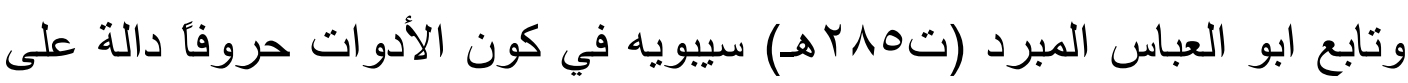

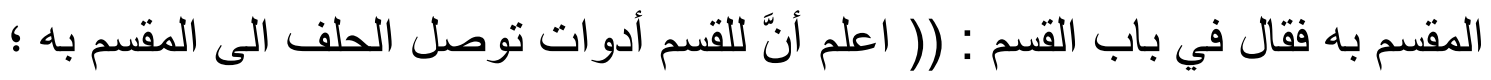

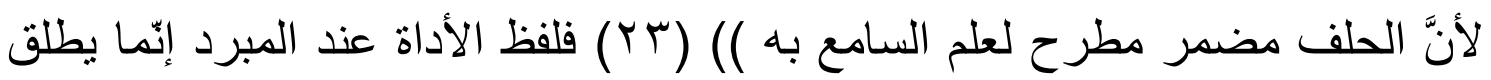

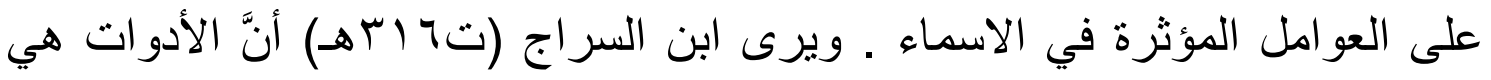

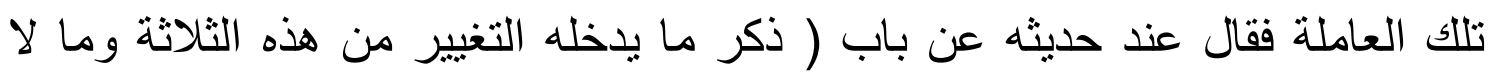

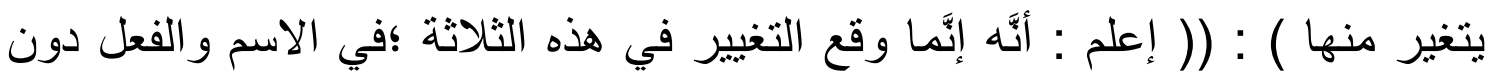

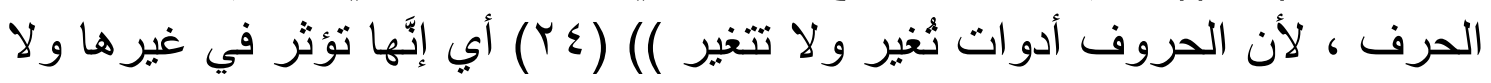

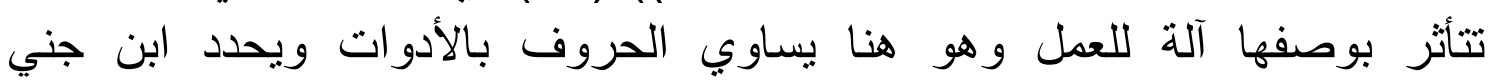




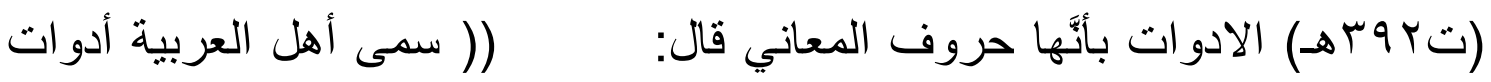

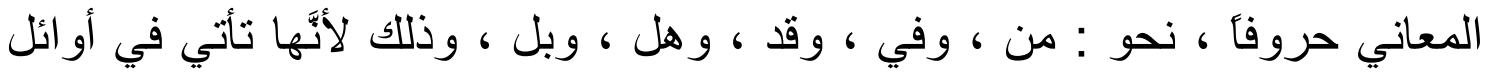

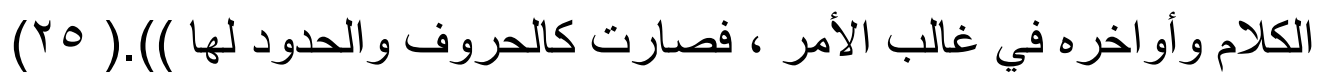

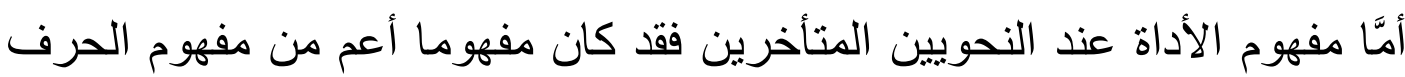

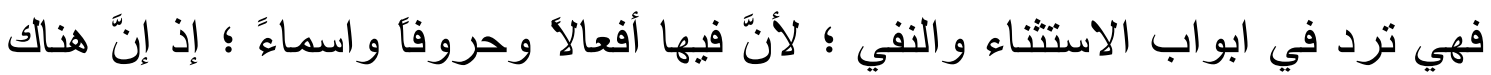
أفعالا تفيد النفي؛ مثل (ليس ، و ولا ) و واسماء مثل (غير) مع استمر ارهم في استعمال

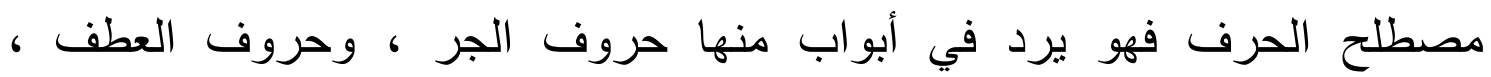

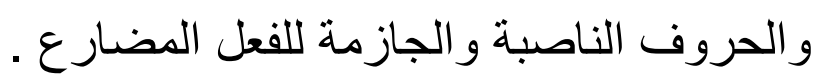

فالأداة عند الجليس الدنيوري ( ت •9 §هـ) مصطلح و اسع المعنى يدخل في أبواب

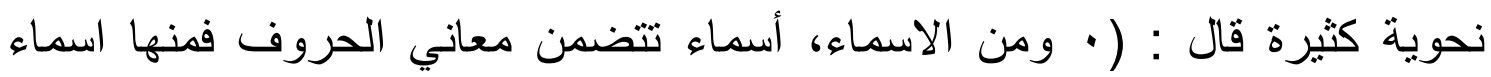

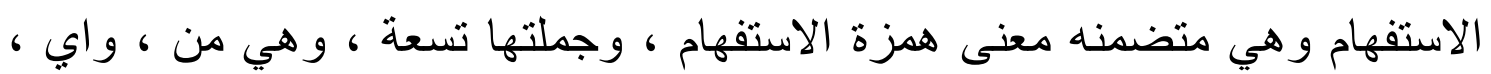

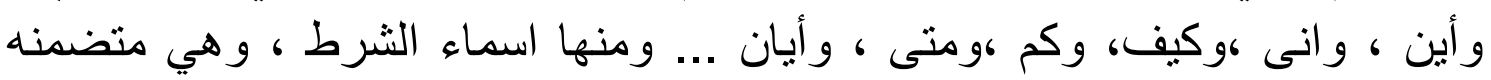

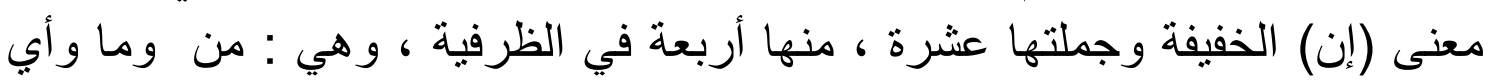

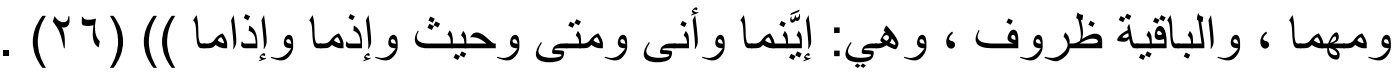

ولا يبتعد العكبري (ت 7 آ7هـ) عن قول الجليس السابق حين قال : (( وأصل

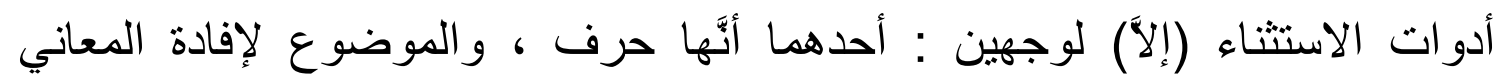

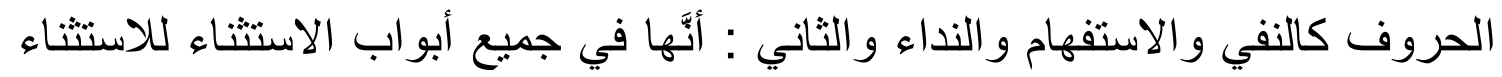

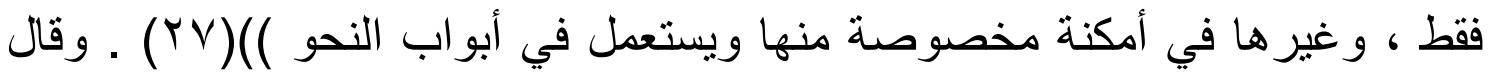

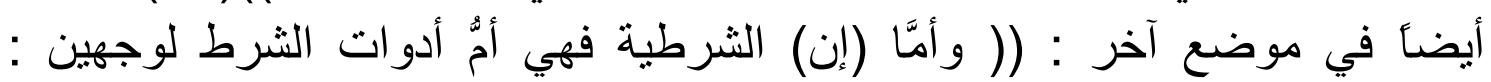

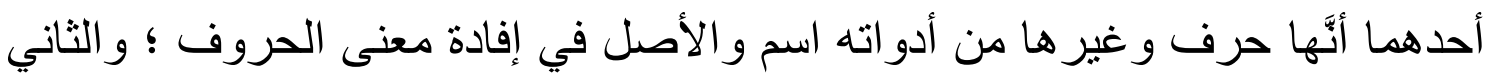

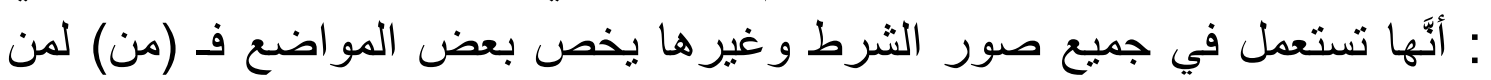

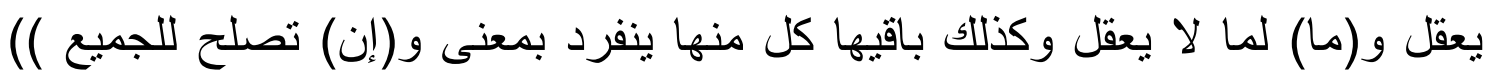

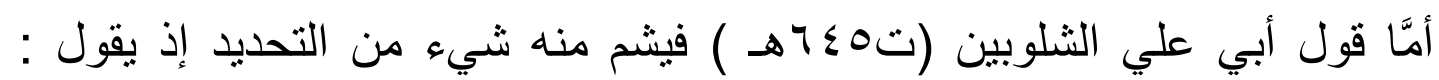

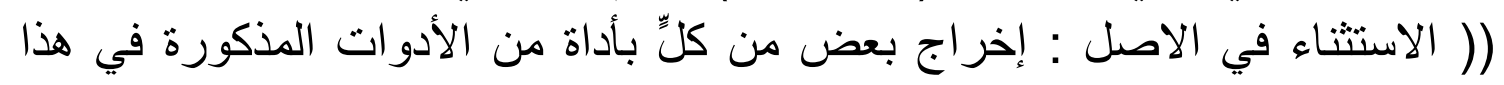

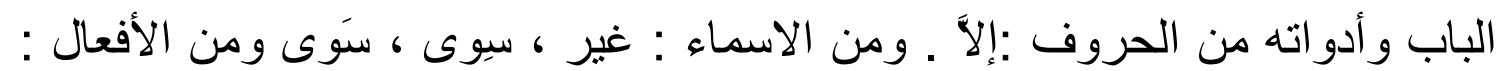

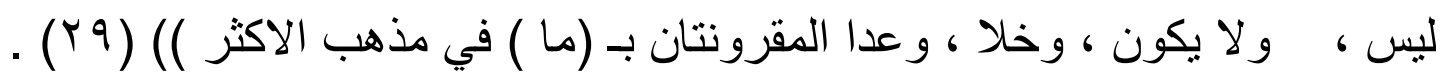




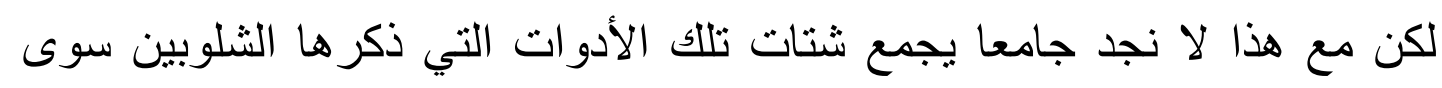

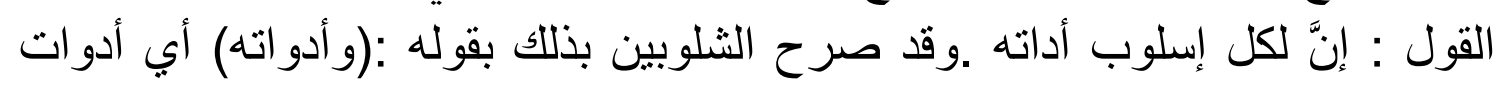

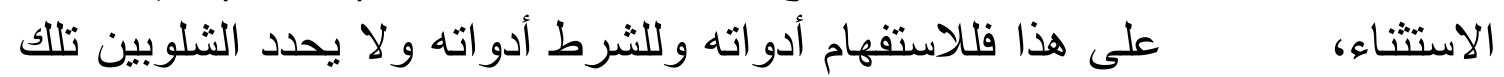

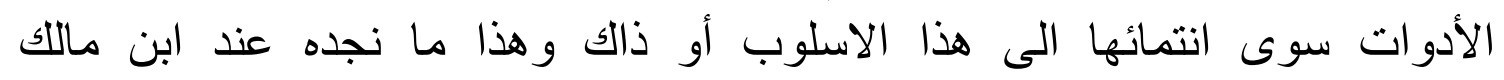

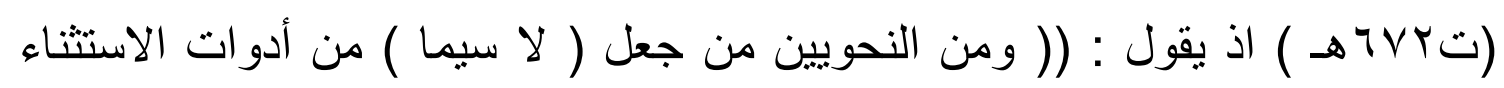

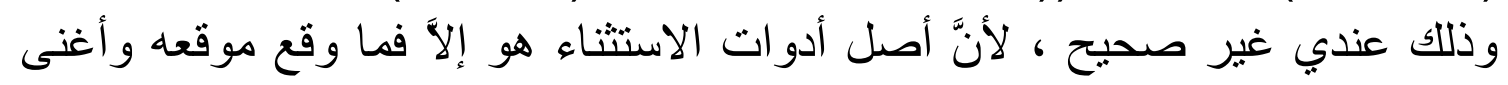

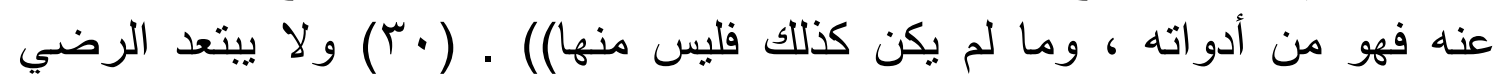

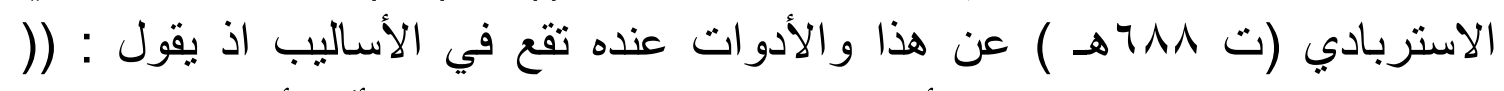

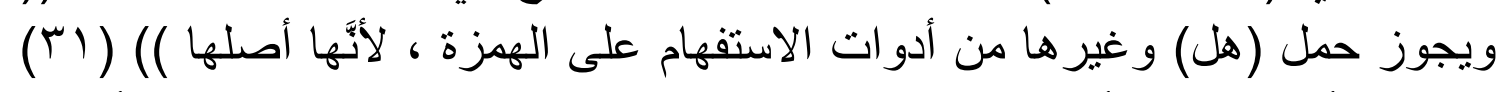

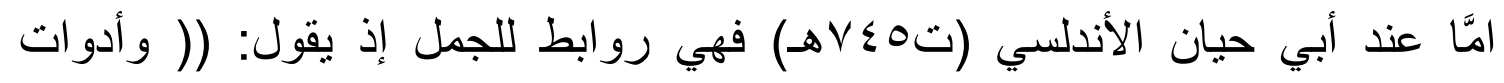

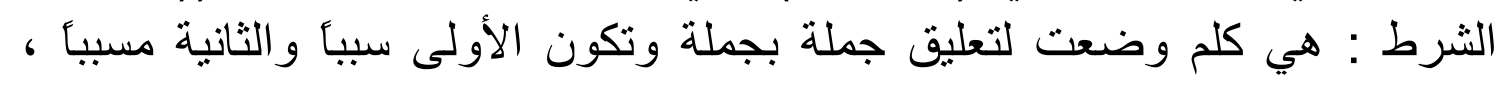

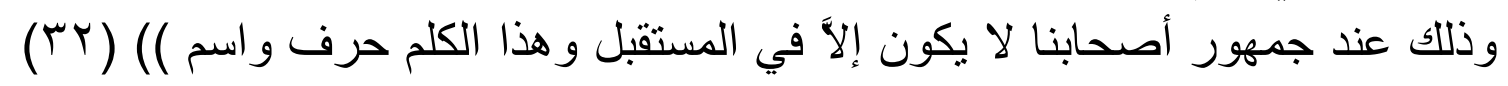

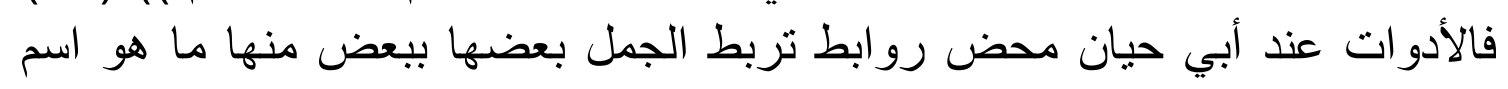

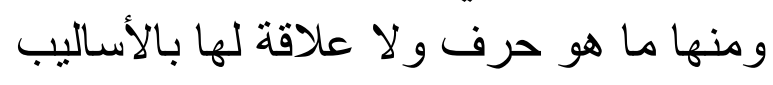

\section{الأداة في كتب معانى الحروف}

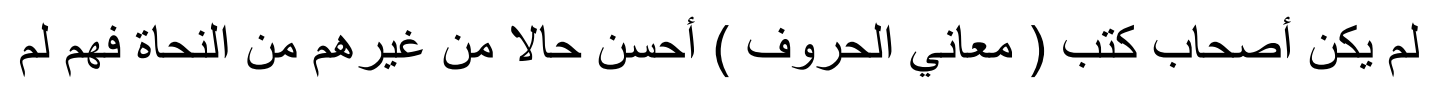

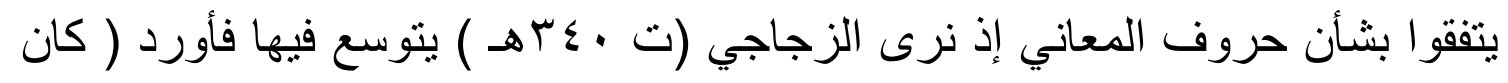

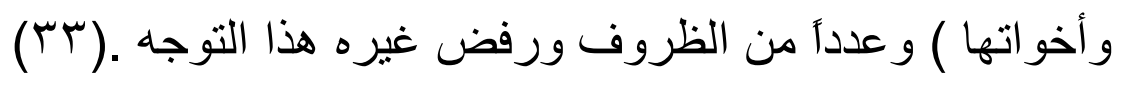

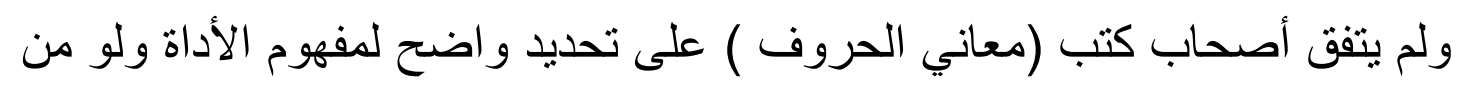

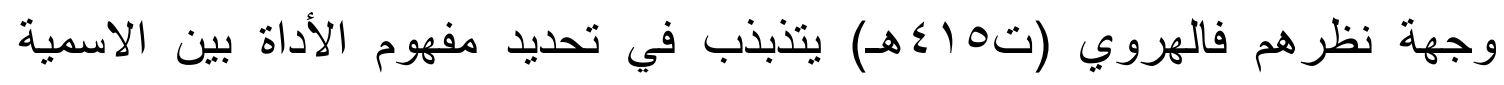

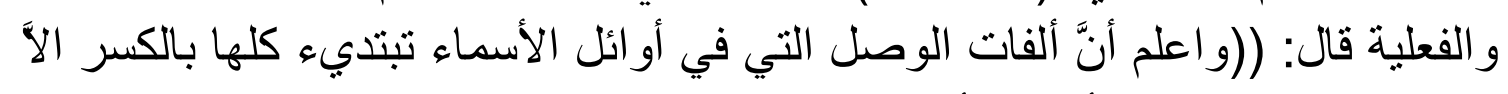

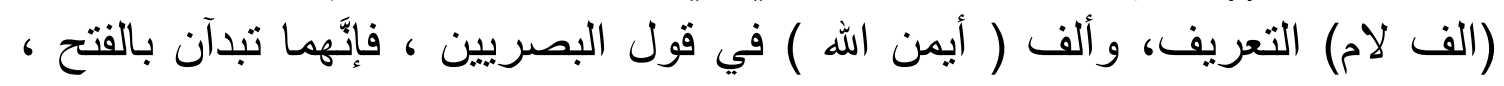

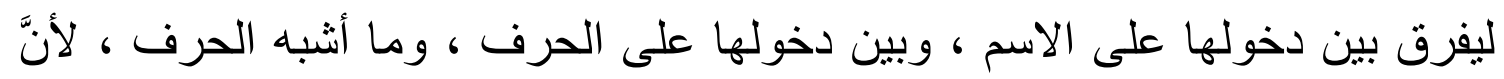

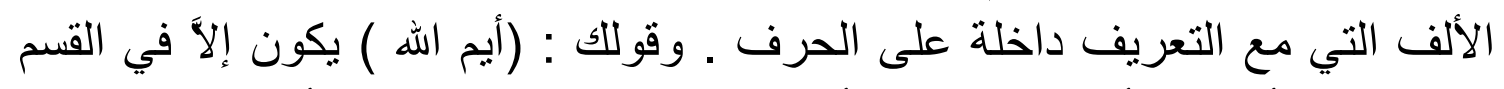

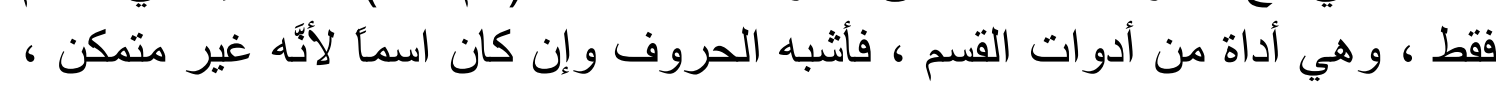

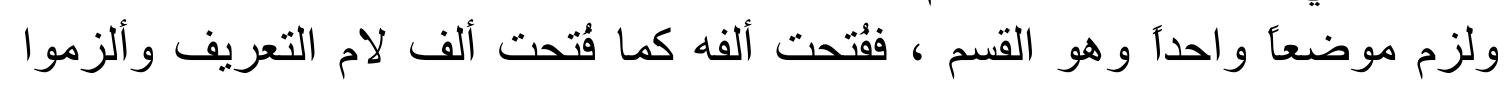

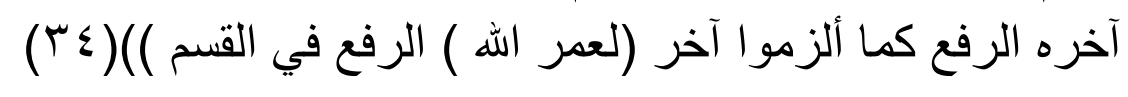

ومع ذلك فلم يخرج أصحاب كتب معاني الحروف عمّا ير اه النحويون فهم يذكرون ما

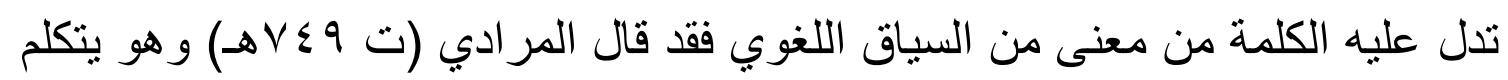


عن عدا: (( عدا : لفظ مشترك ، ليكون حرفأ ، وفعلا. وهو في الحالين من أدوات

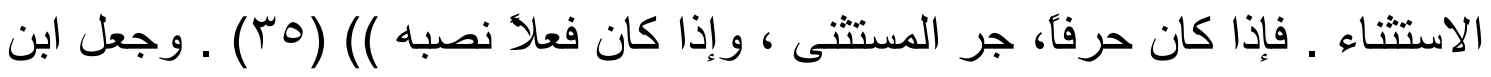

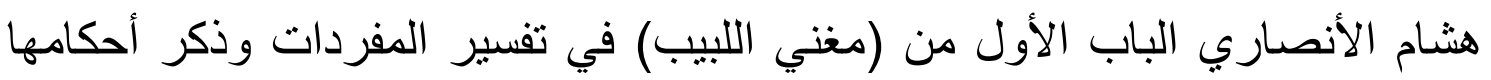

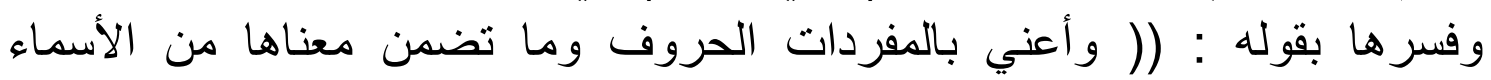

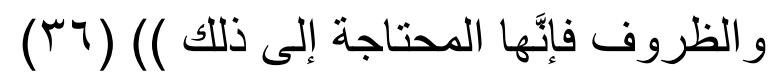

ويبدو أنَّ استعمال ابن هشام لفظ (المفردات) للالالة على الحروف وما تضمن

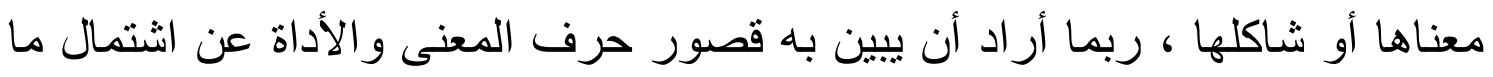

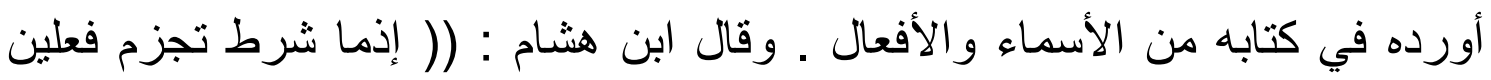

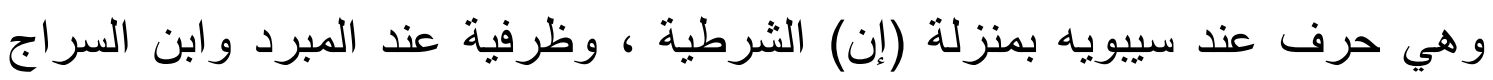

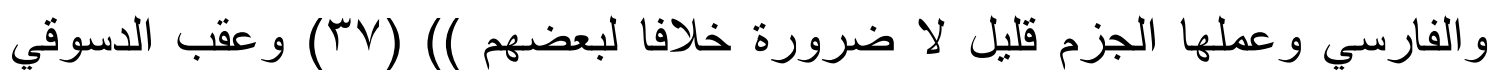

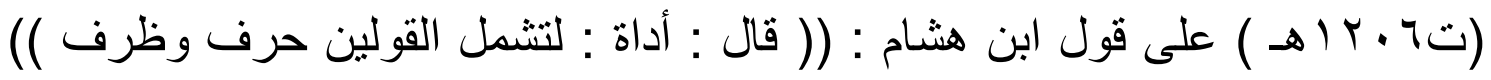

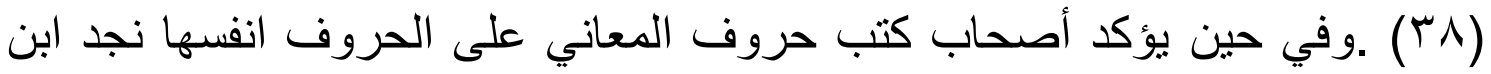

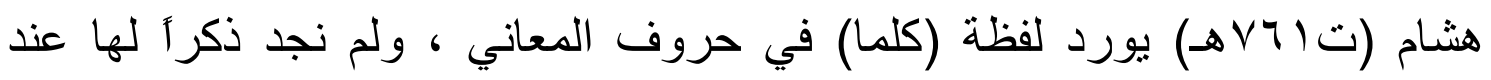

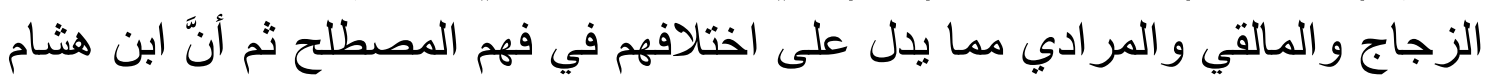

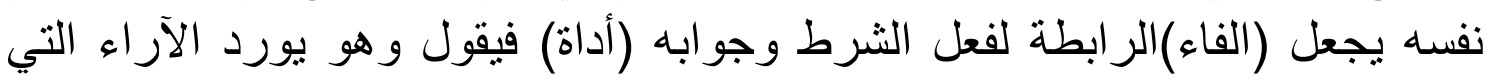

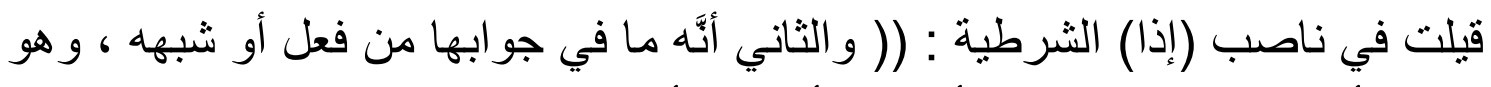

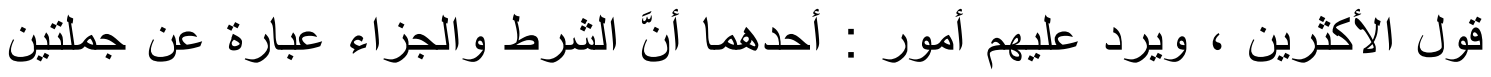

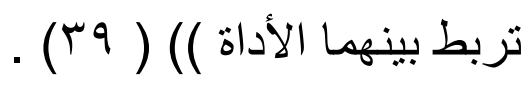

\section{رأي النحويين المحدثين :}

أمَّا النحويون المحدثون فمنهم من حاكى الموروث القديم بل اعتمده في توصيف

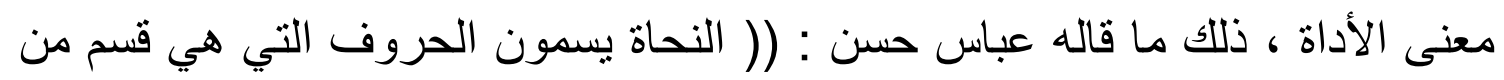

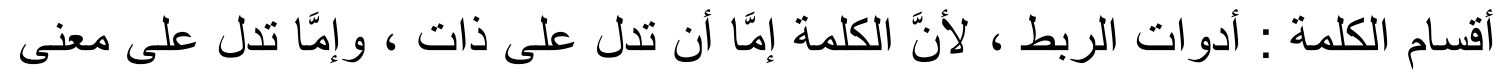

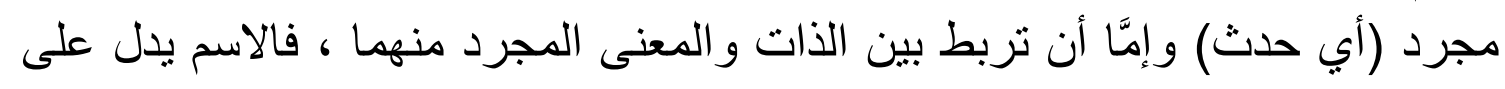

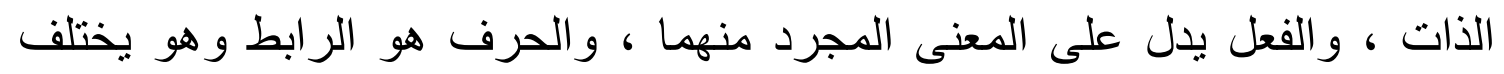

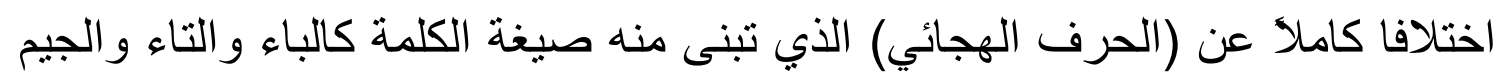

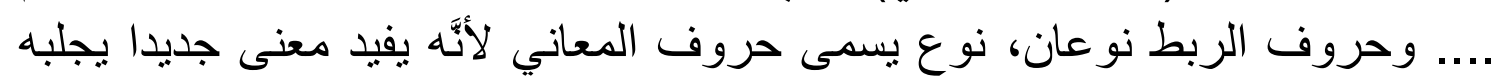

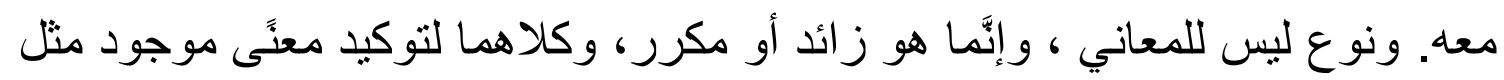

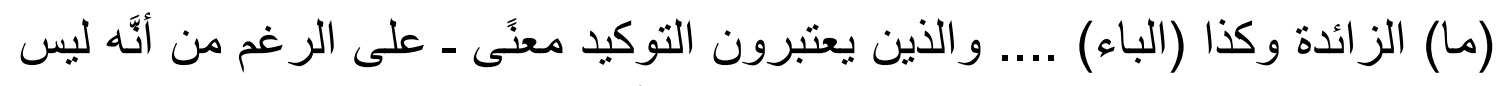

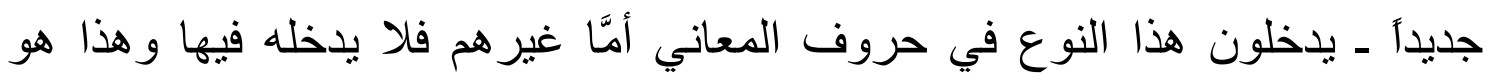


المشهور)) ( • ( ). وقسَّم الدكتور أميل بعقوب الأداة بعد أن جمع آراء النحويين فيها

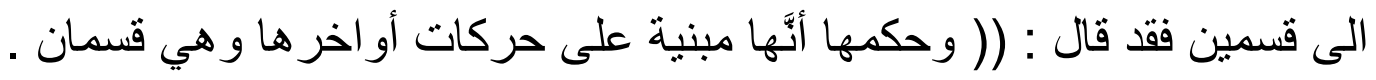

ا ـ قسم يتضمن كل حروف المعاني في اللغة العربية. وكل الحروف التي لا محل لها

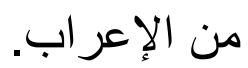

rـ قسم يتضمن أسماء ،كأسماء الشرطو الاستفهام ، و الاسماء نُعرب بحسب موقعها

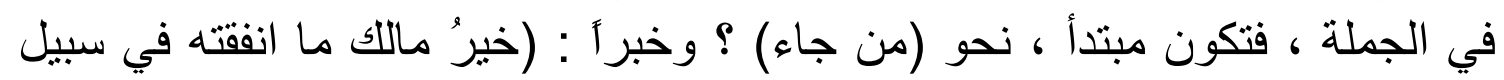

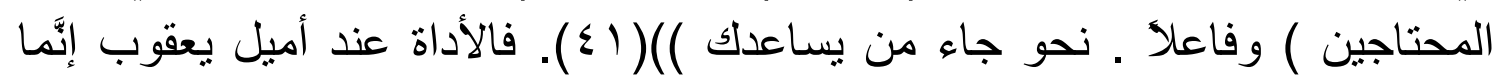

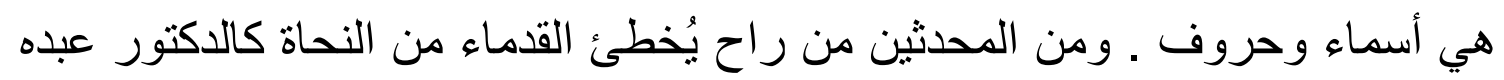

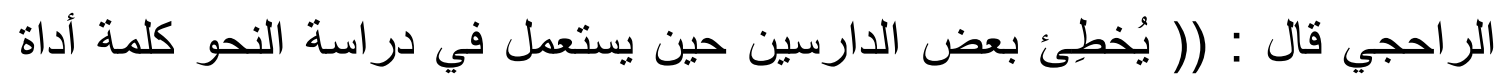

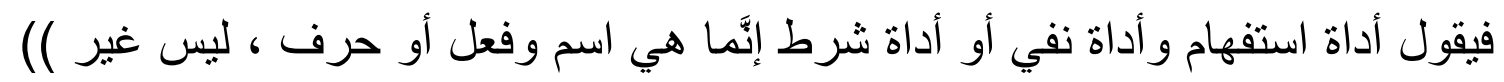

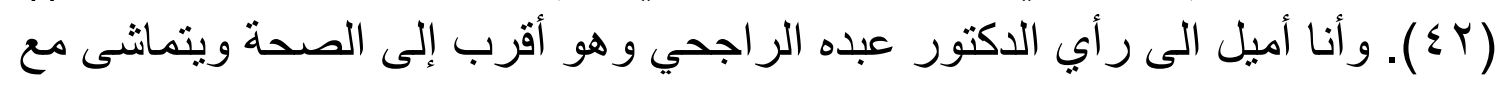

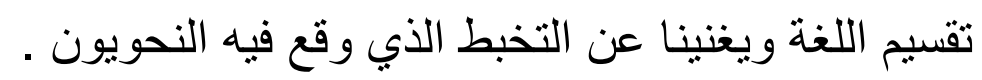

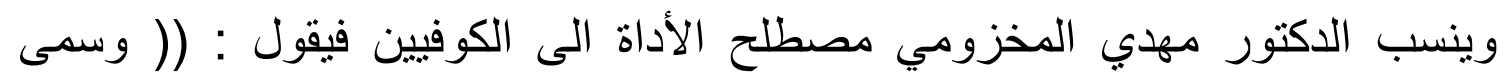

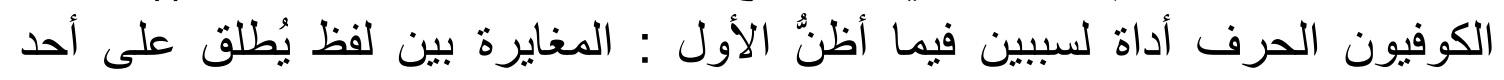

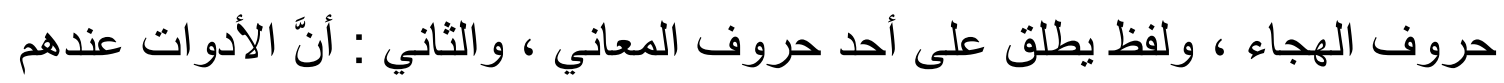

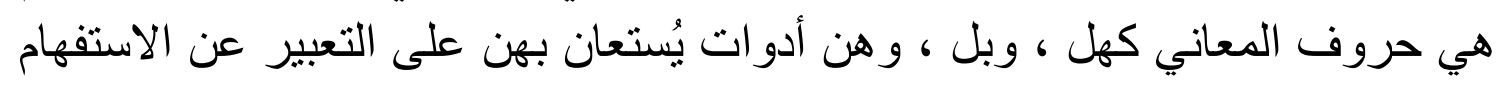

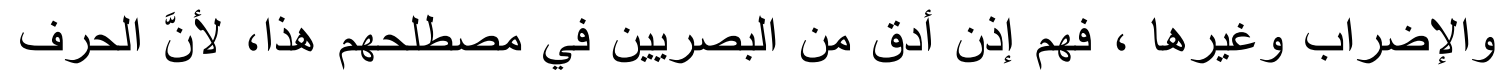

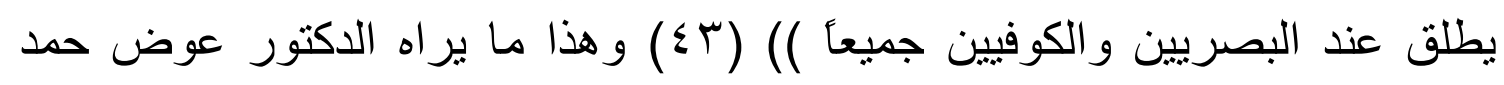

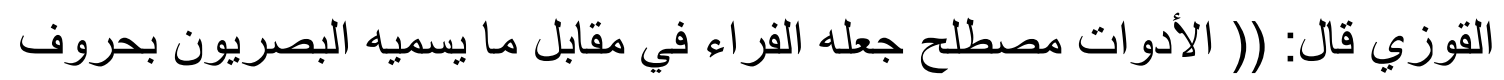

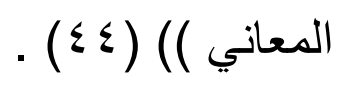

لكن المشكل ليس هو استعمال المصطلح أوعدم استعماله إنَّما المشكل هو تحديد

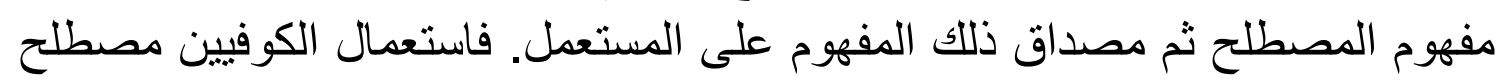

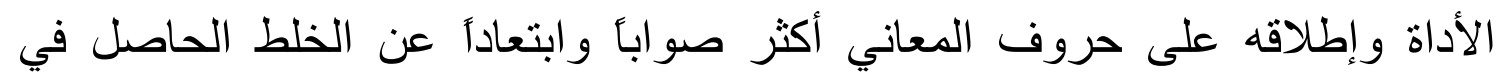

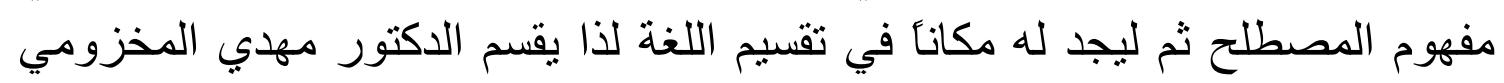

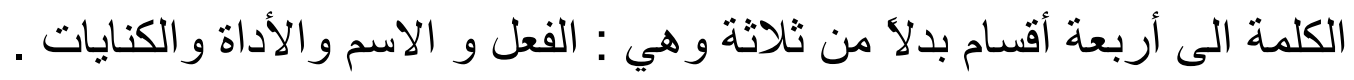

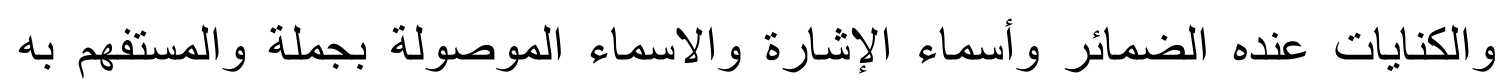

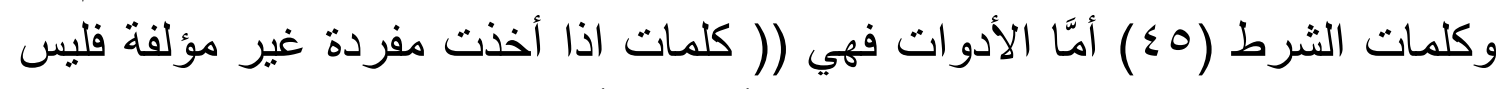

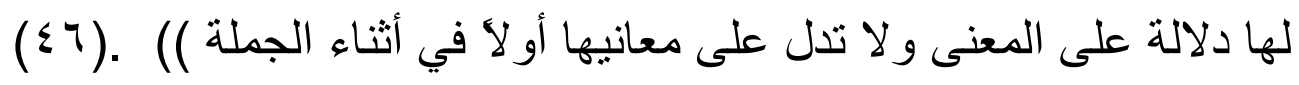


أمَّا الدكتور تمام حسان فالأداة عنده إمَّا أصلية و إمَّا محمولة. فالأصلية عنده هي

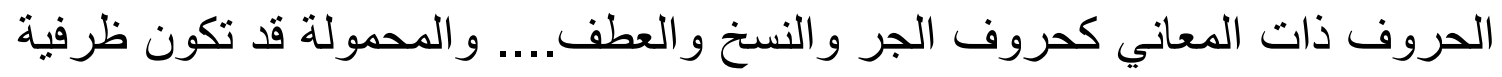
أو اسمية أو فعلية أو ضميرية. (گV)

و لا يفوتنا ذكره أنَّ الدكتور تمام حسان يقسم الكلام الى سبعة أقسام :

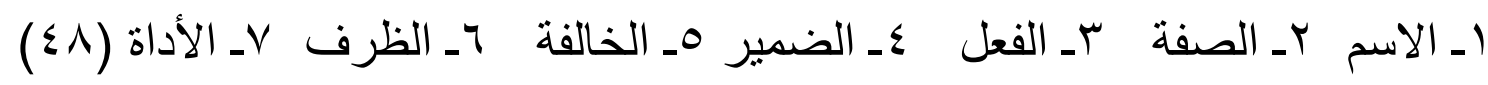

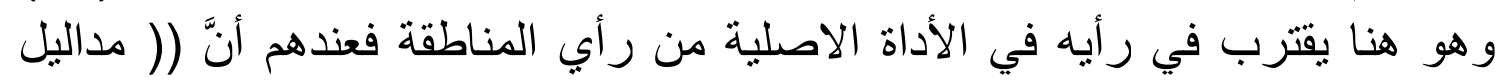

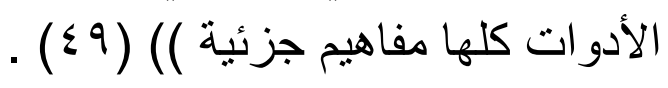

واللافت للنظر أنَّ تقسيم النحوبين المحدثين الكلام الى أربعة أقسام إنَّما هو تقسيم المناطقة على ما سنرى .....

\section{الأداة عند المناطقة}

لم يكن المناطقة بعيدين عن در اسة اللغة و الإحاطة بها علمَ أنَّ المفكرين ظلو ا بعد

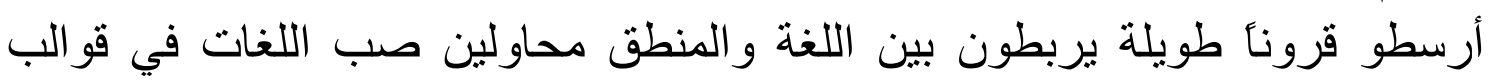

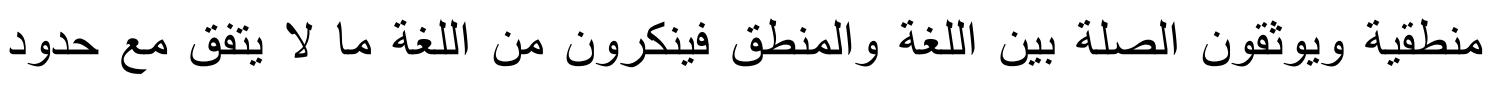

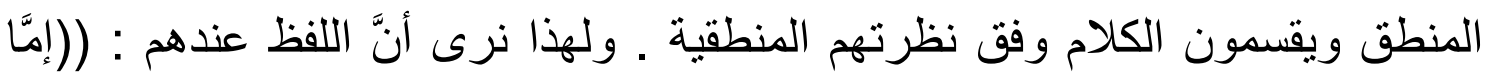

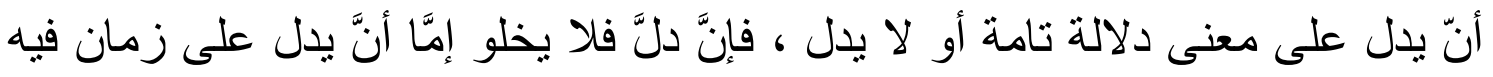

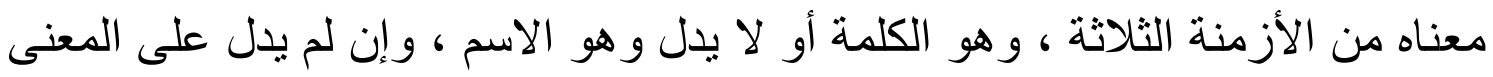

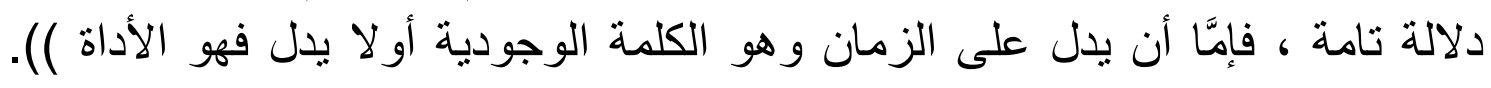

وقد تلتقي المصطلحات النحوية المنطقية مع المصطلحات النحوية المعروفة وقد

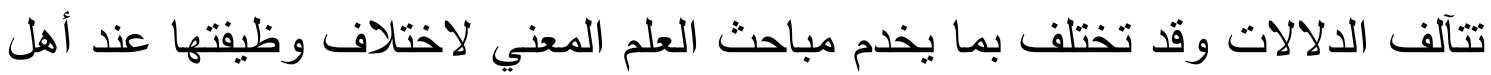

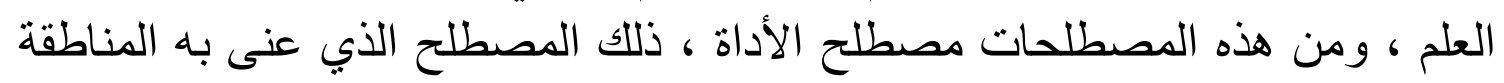

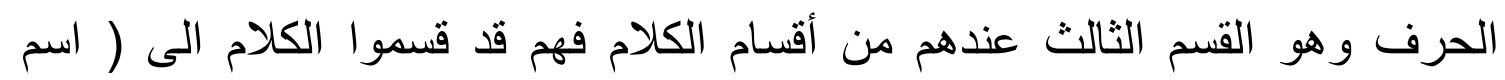

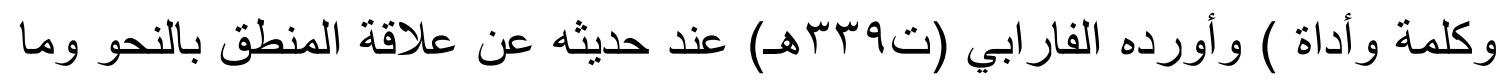

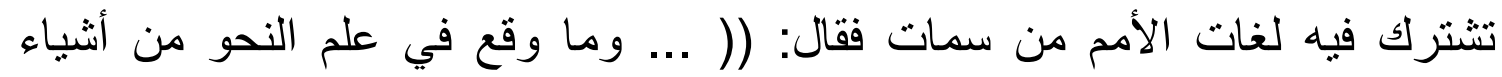

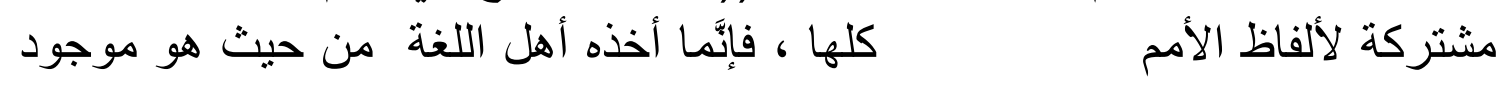

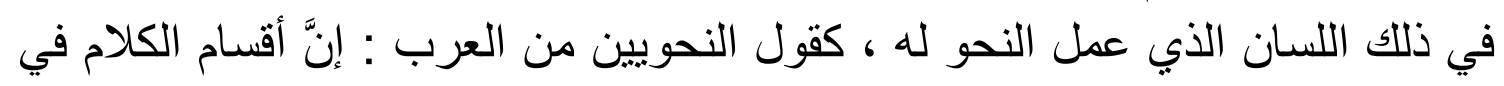

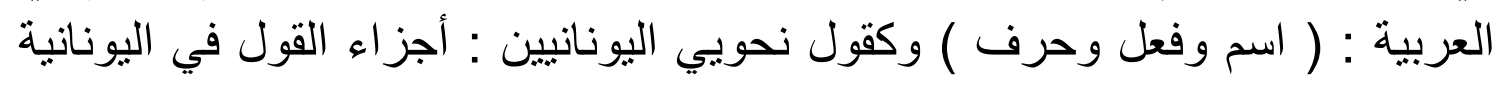

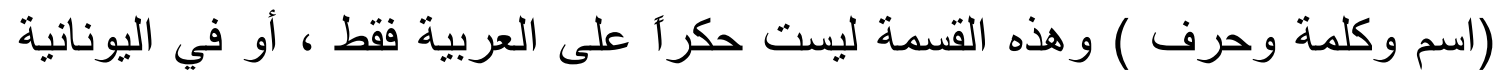


فقط ، بل في جميع الألسنة ، وقد أخذها نحويو العرب على أنَّها في العربية ، ونحويو

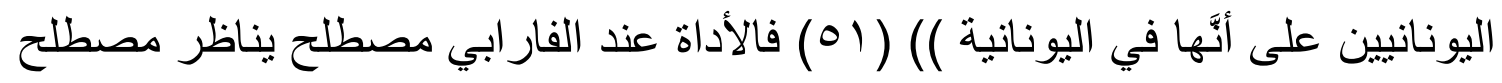

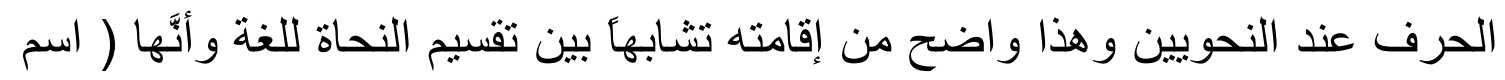

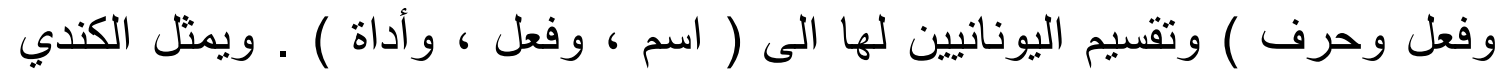

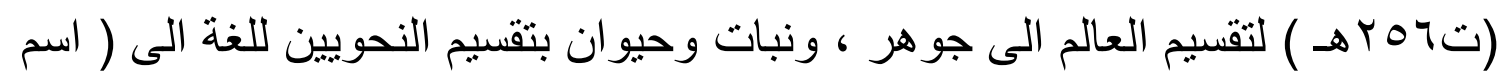

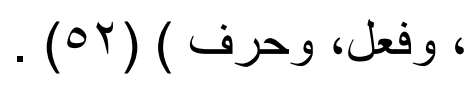

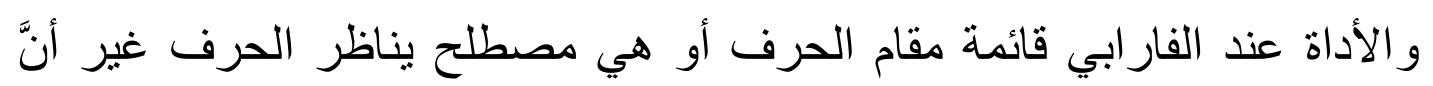

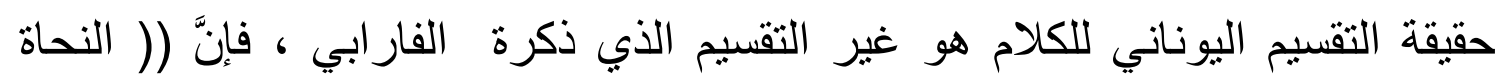

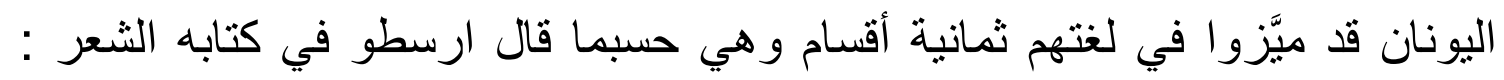

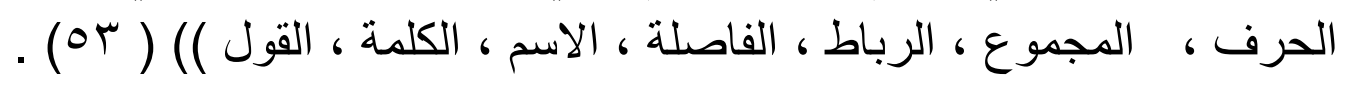

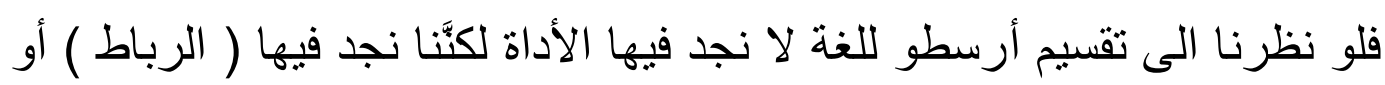

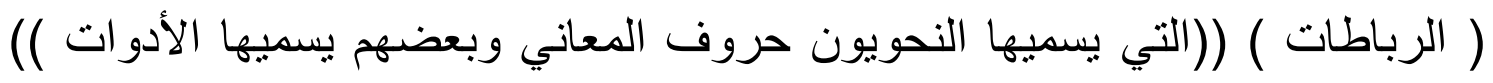

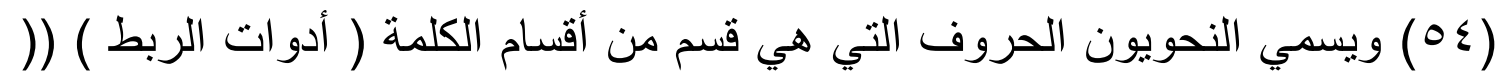

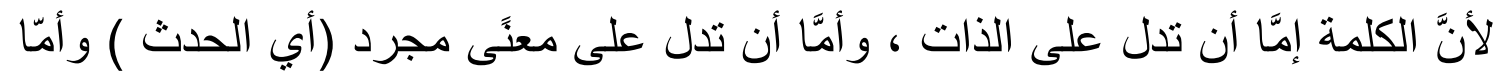

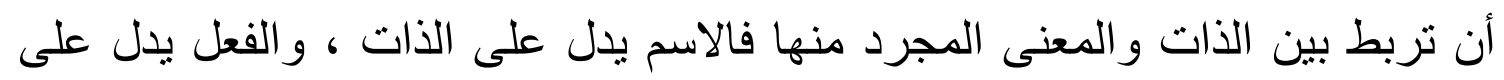

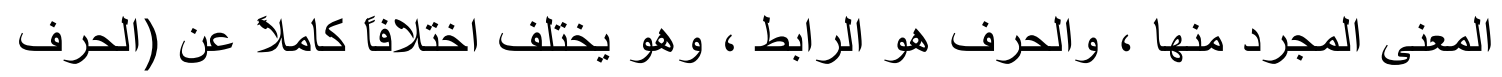

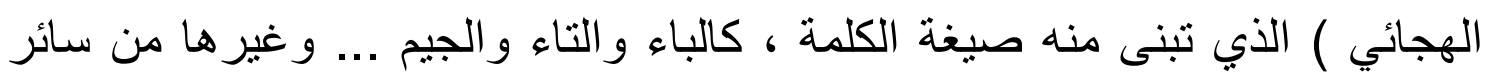

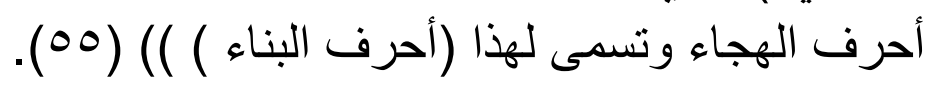

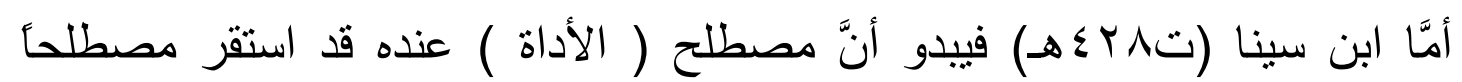

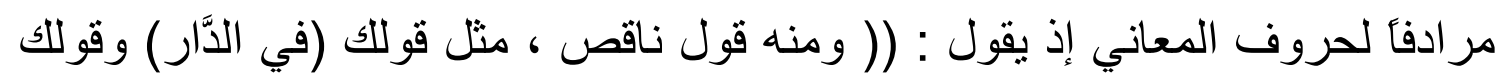

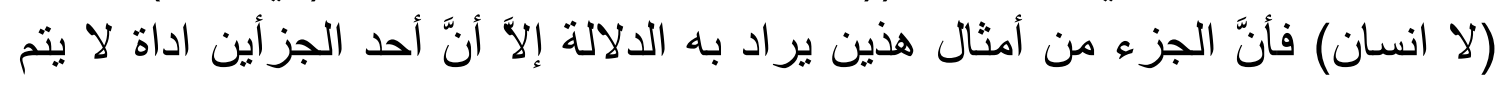

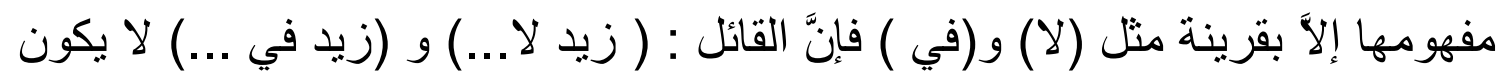

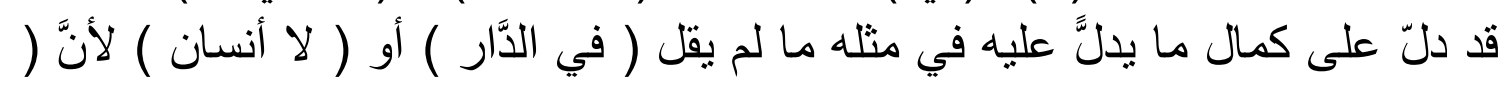
في ) و (لا) أداتان ليستا كالأسماء و الأفعال )) (

على الرغم مع هذا الذي وجدناه من تطور مفهوم الأداة عند متقدمي المناطقة فإنَّ

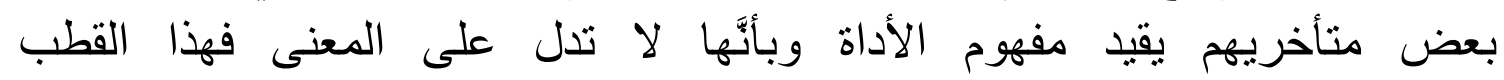

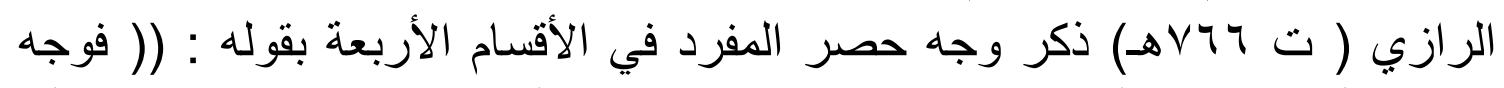

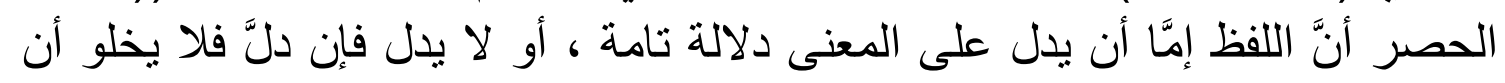

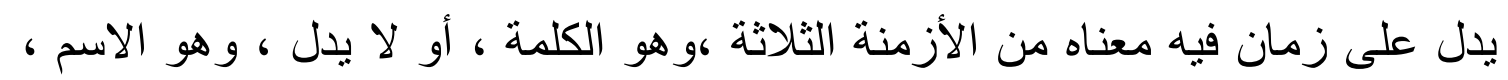




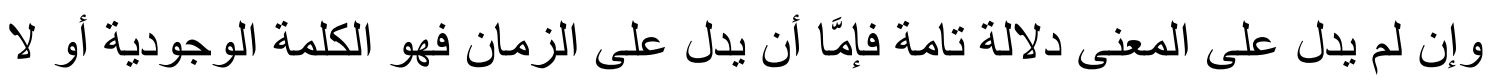

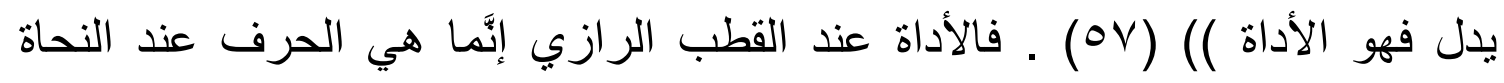

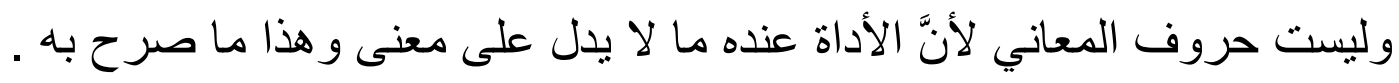

\section{الأداة عن المناطقة المحدثين :}

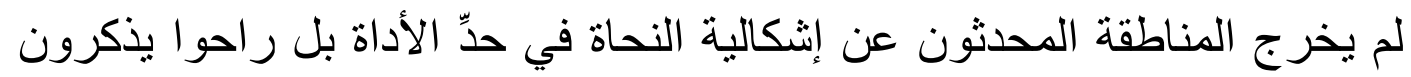

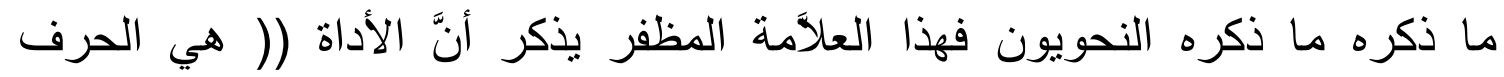

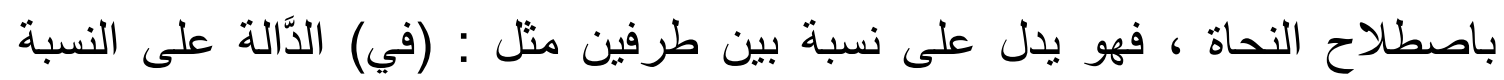

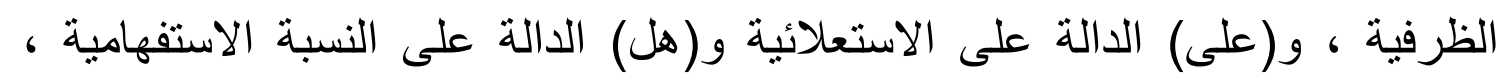

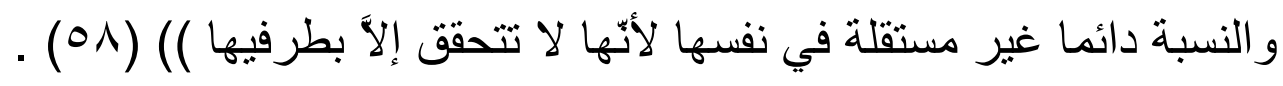

ويقصد بالنسبة المعنى الذي يضيفه الحرف من ظرف و استعلاء و استفهام غير أنَّ

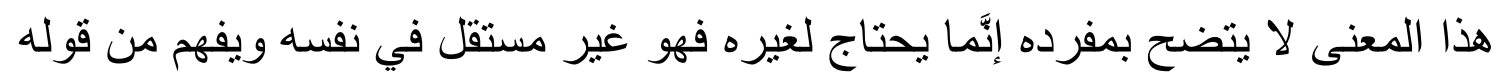

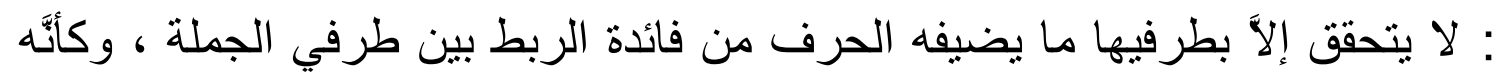

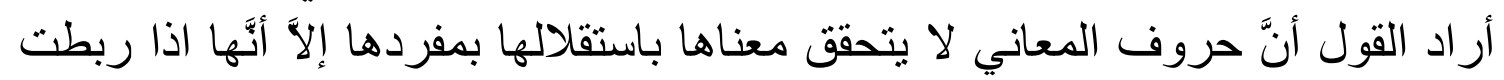

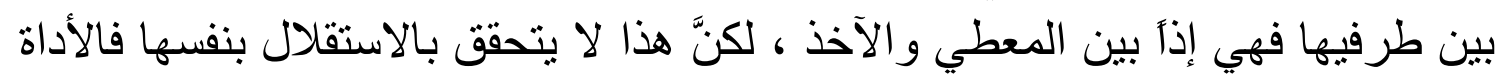

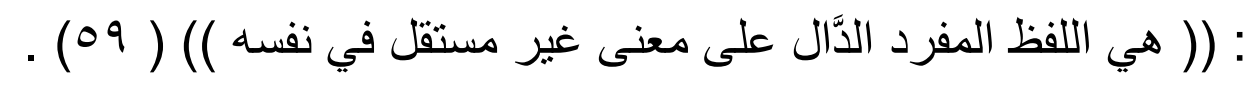

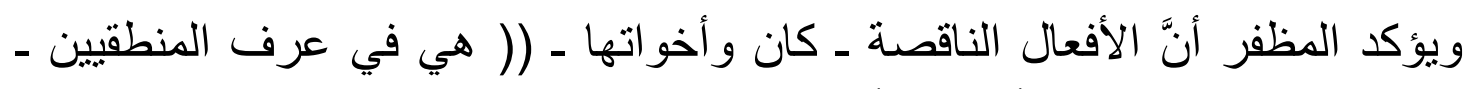

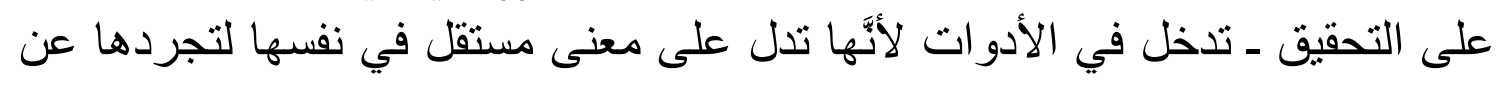

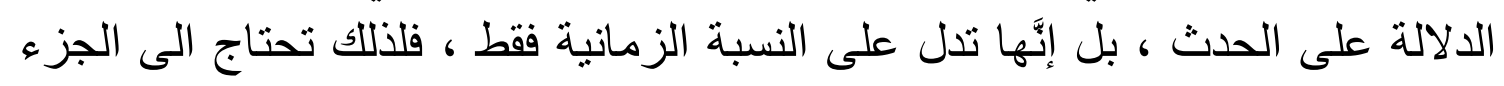

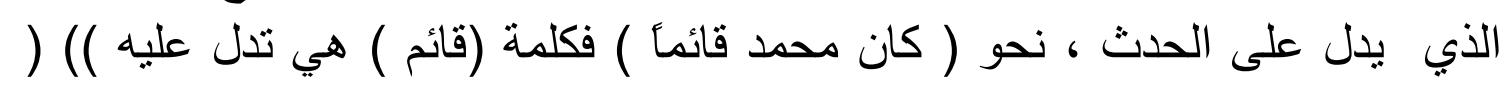

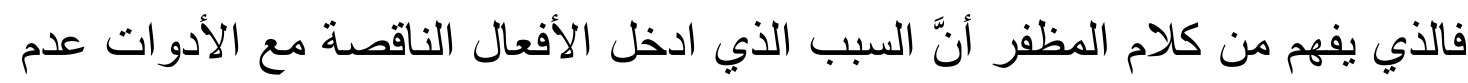

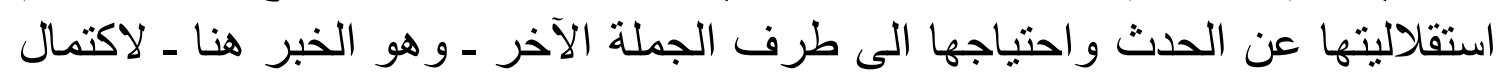

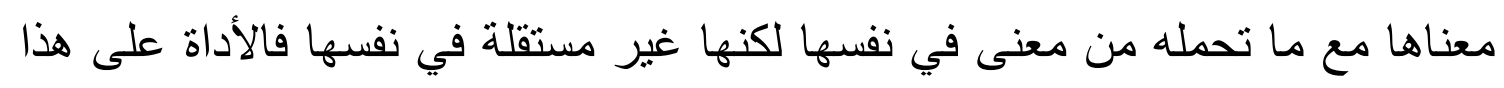

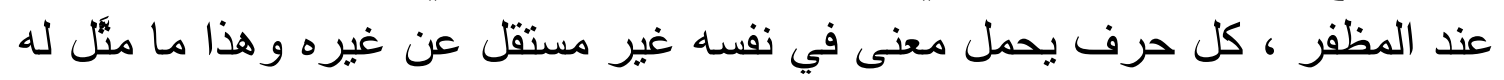

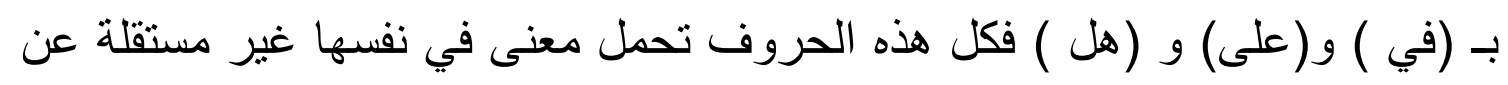

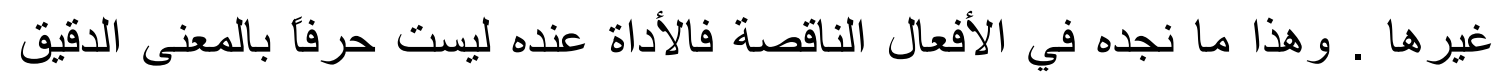

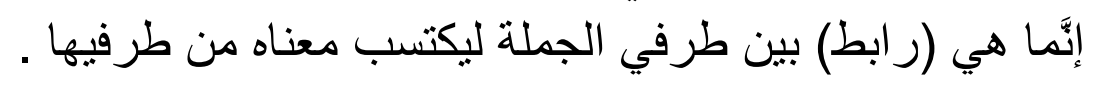


غير أنَّ الخلاف قد وقع بين المناطقة أنفسهم في كون الأفعال الناقصة من الأدوات

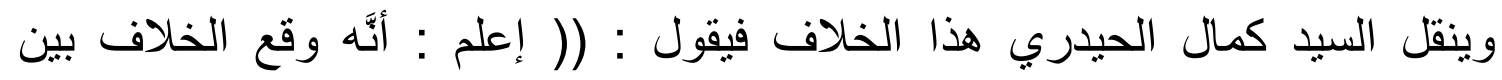

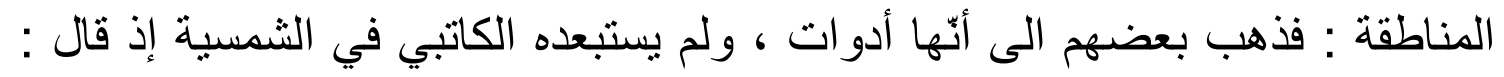

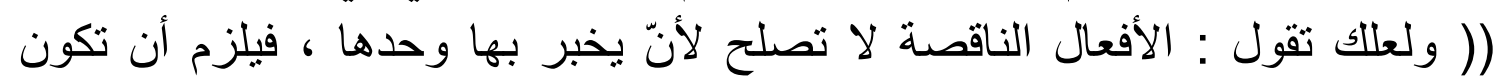

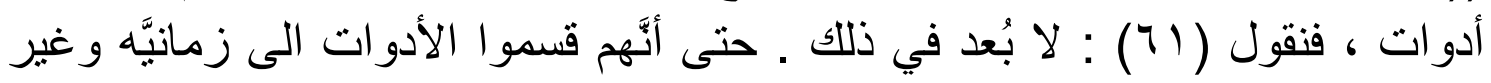

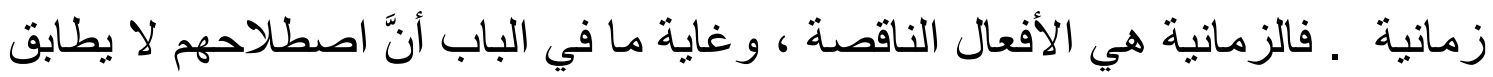
اصطلاح النحاة . فالنة مانية

وذهب بعضهم ، كالقاضي في المطالع والقطب الثبرازي في الدرة ، الى أنّها أفعال تسمى ( الكلمات الوجودية ) كالقوية

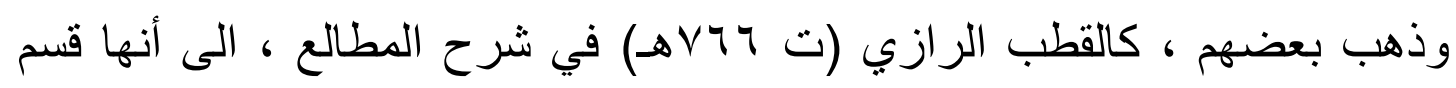

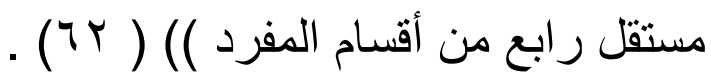

ثمَّ أنَّ بعضهم جعل ضمائر الفصل ضمن الأدوات جاء في كتاب المقرر للسيد

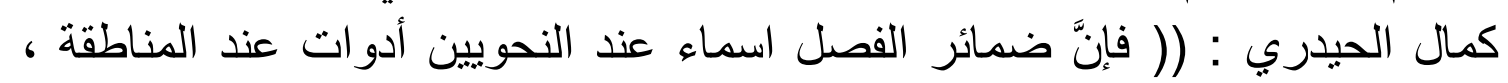

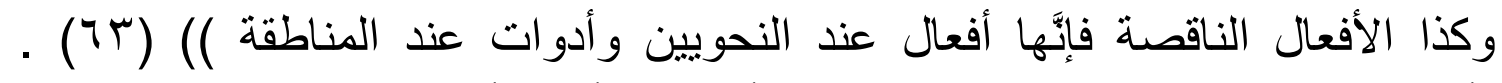

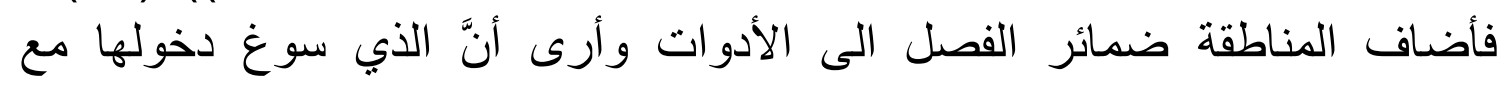

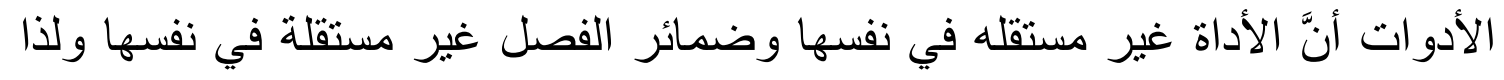

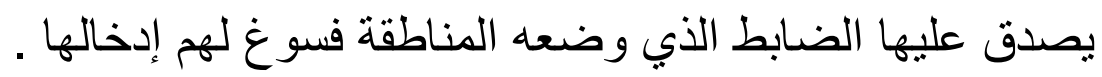

وتحتاج الأداة عند المناطقة الى متعلق يقول الدكتور محمد رمضان : (( والأداة

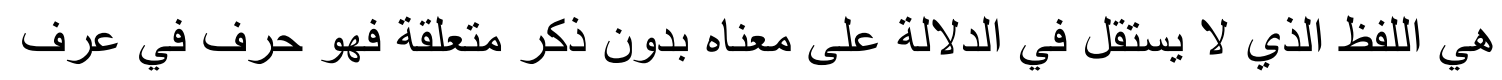

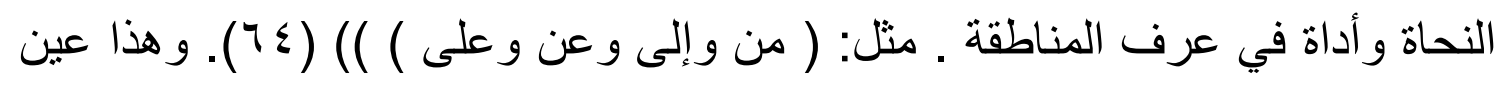

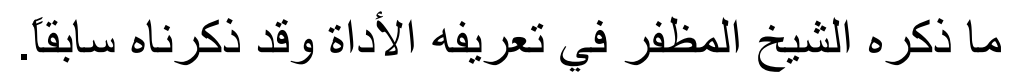

لكن ليس كل ما يصدق عليه اصطلاح النحاة يصدق عليه اصطلاح الأداة عند

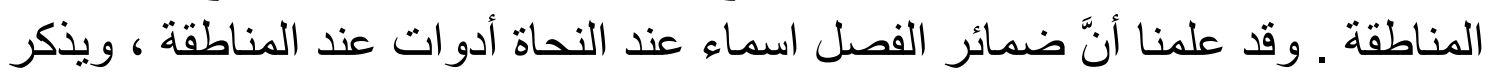

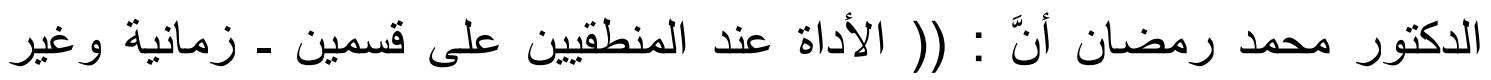

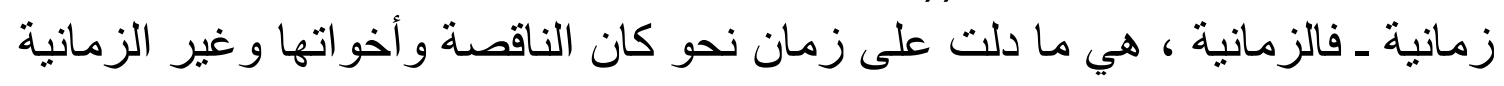

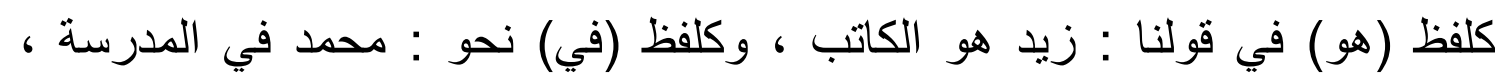

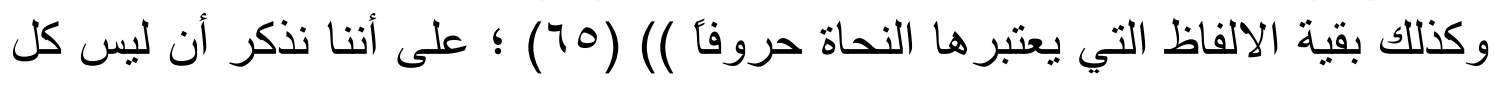

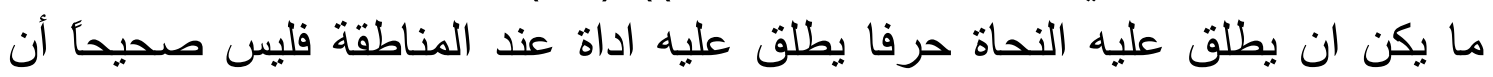


الأداة عند المناطقة حرف عند النحاة فالأفعال الناقصة أفعال عند النحاة أدوات عند

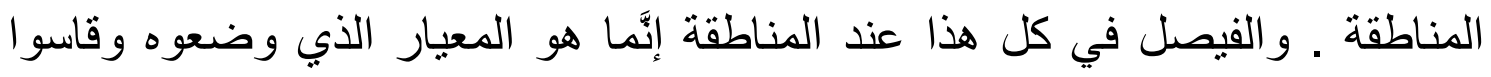

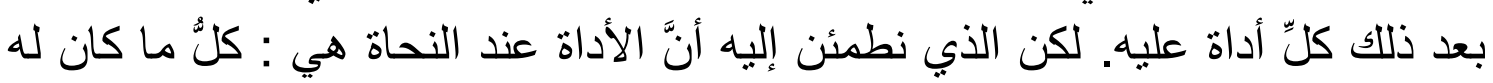

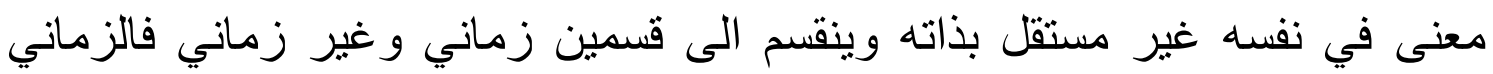

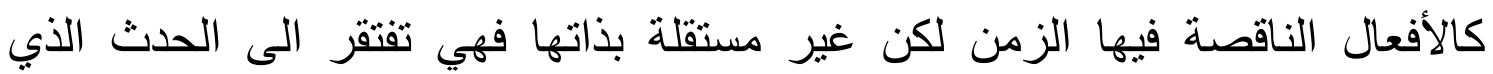

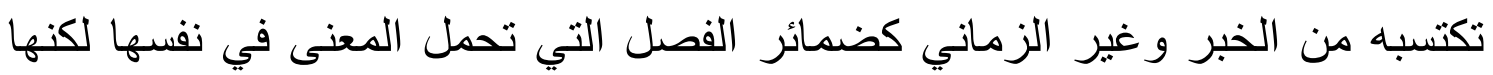

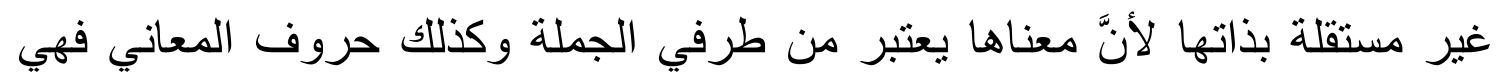

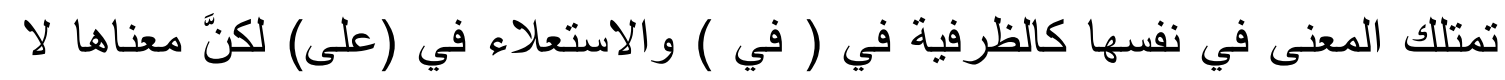
يعتبر إلآَ من طرفي الجملة (زيد في الدار ) . لكنَّ الحق أن يقال: (( انَّ نسبة هذا المصطلح للفلاسفة لا يطالعنا في كتب

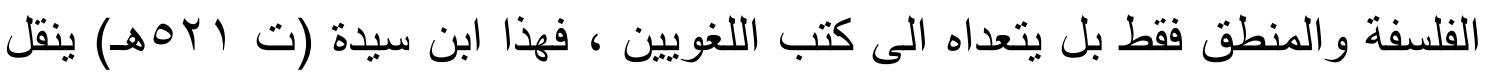

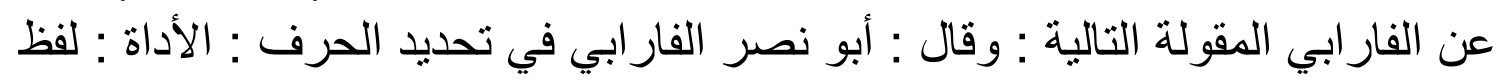

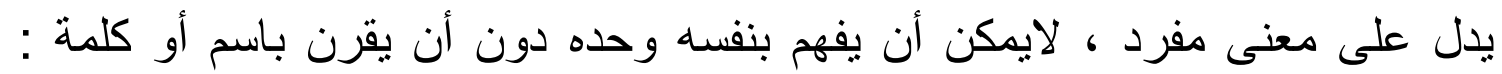

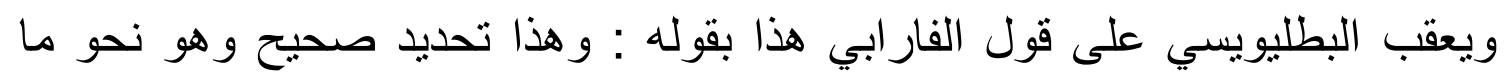

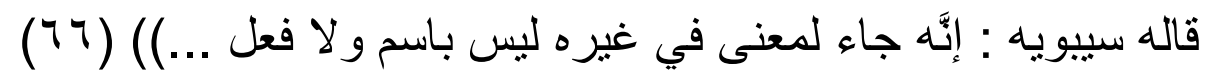

ومما ذكر يتضح لنا سعة التداخل بين علمي النحو و المنطق سواء كان هذا التداخل

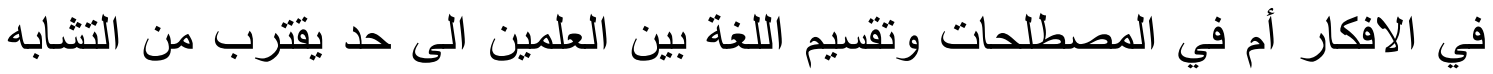
ولعل الأداة هي أحدى حلقات التشابه بين العلمين وإن كان العنان العناطقة أكثر تحديدا

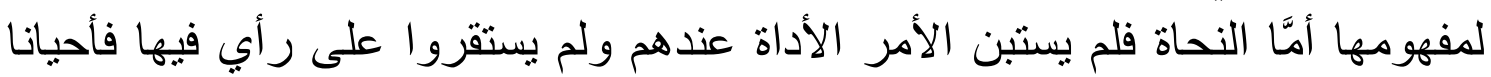

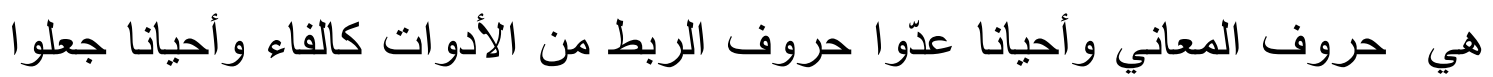

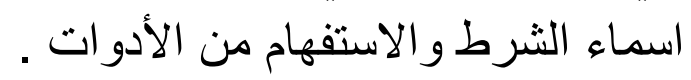

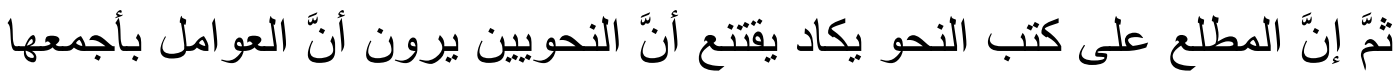

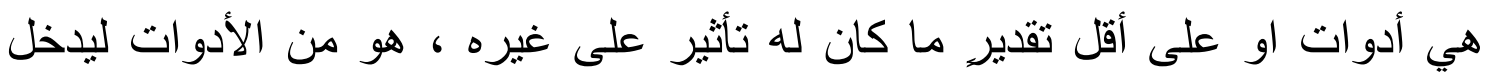

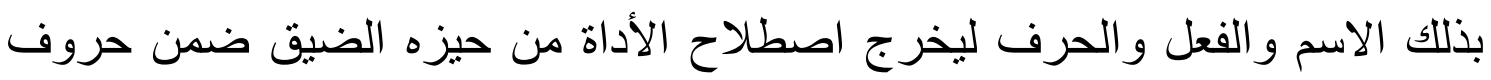

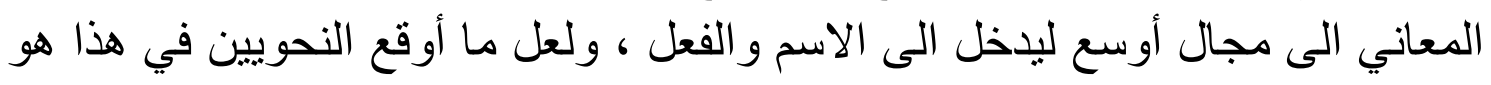

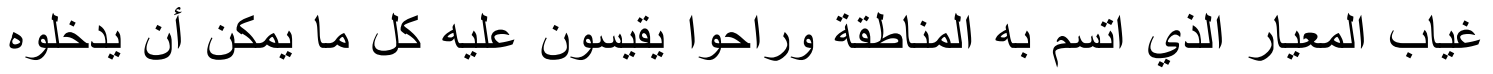

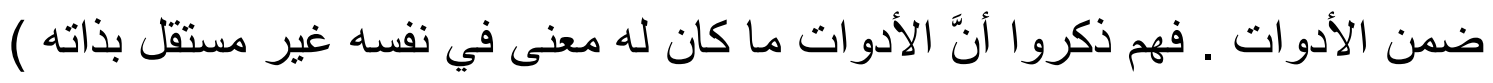

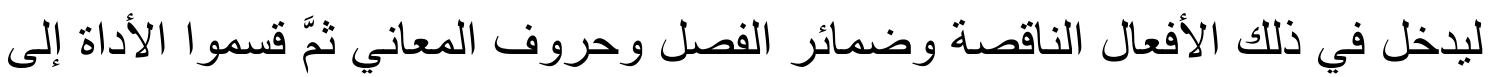

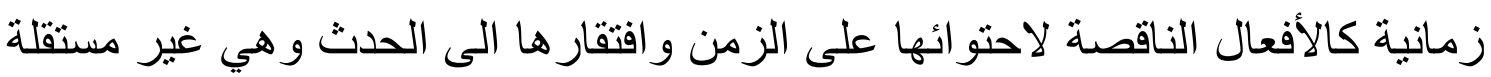


بذاتها وغير الزمانية وهي ضمائر الفصل وحروف المعاني لاحتو ائها على معنَّى في

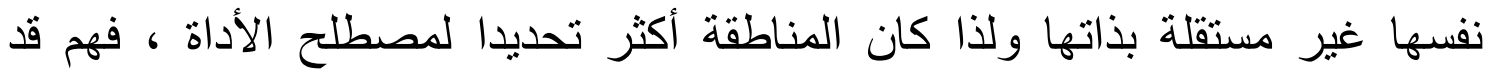

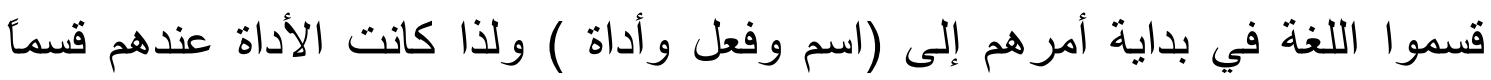
خاصأ له ضابط يضبطه ومعيار يقاس عليه ما يدخل تحته

أمَّا النحويون عامة و لا سيما البصريون فالأداة عندهم مصطلح طارئ لا يدخل

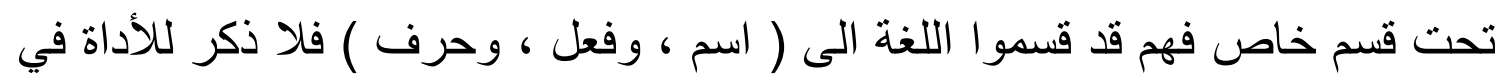

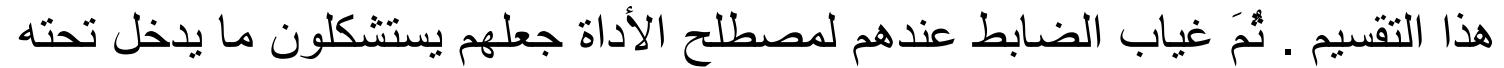

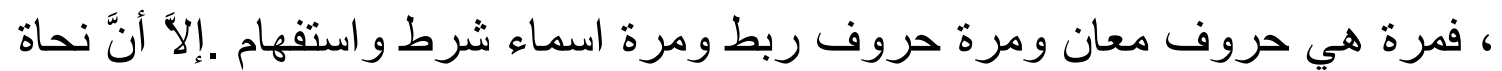

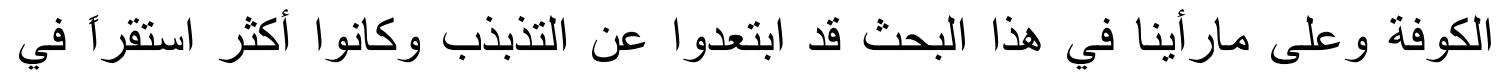

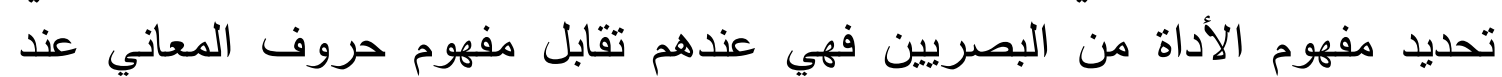

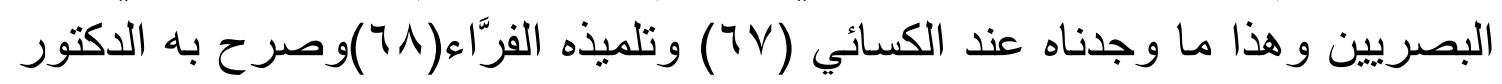
مهدي المخزومي (79) - (79)

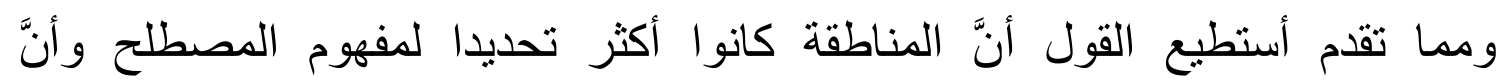

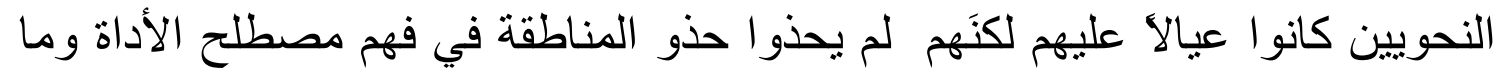

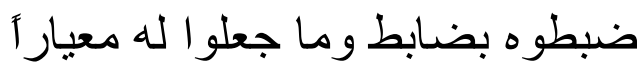




$$
\begin{aligned}
& \text { هوامش البحث }
\end{aligned}
$$

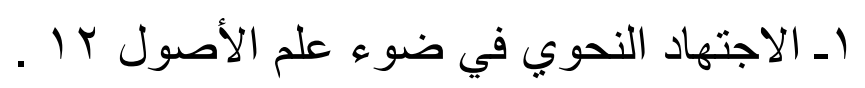

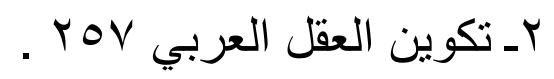

$$
\begin{aligned}
& \text { rـ الألفاظ المستعملة في المنطق ؟ـ. } \\
& \text { عـ ينظر : عيون الأنباء في طبقات الأطباء } 9 \text { ـ 7. ومؤلفات للفار ابي rV. }
\end{aligned}
$$

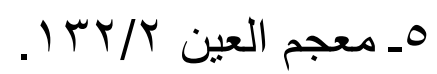

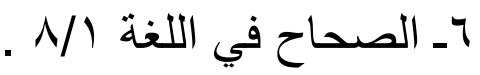

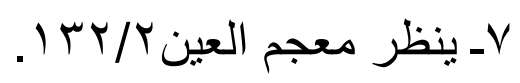

$$
\begin{aligned}
& \text { Aـ الحلل في إصلاح الخلل من كتاب الجمل VT. } \\
& \text { 9ـ المحكم و المحيط الأعظم r/ } 7 \text { ـ ـ مادة (رف) . }
\end{aligned}
$$

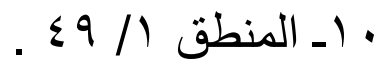

$$
\begin{aligned}
& \text { 1 اـ الإتقان في علوم القرآن / /ع . . . }
\end{aligned}
$$

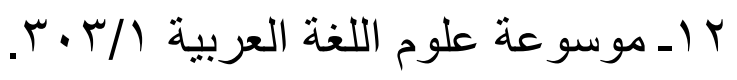

$$
\begin{aligned}
& \text { بـ ـ الخلاف النحوي في الأدوات ^. }
\end{aligned}
$$

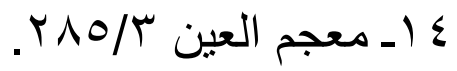

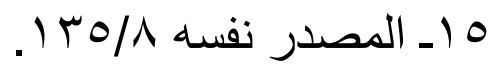

$$
\begin{aligned}
& 7 \text { ـ ـ ـ مقدمة في النحو هب. } \\
& \text { I ا سورة الأنبياء OV }
\end{aligned}
$$

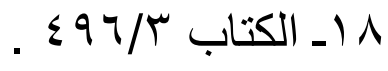

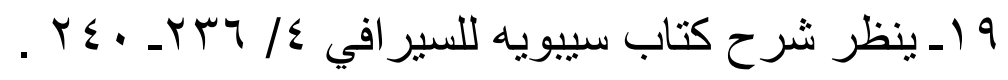

$$
\begin{aligned}
& \text {. }
\end{aligned}
$$




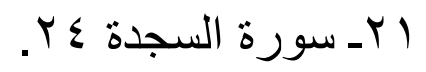

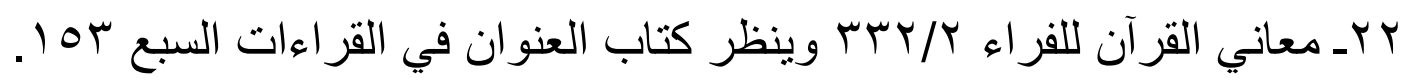

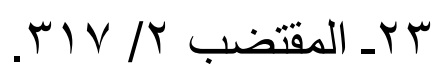

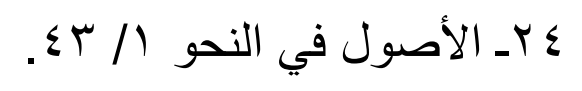

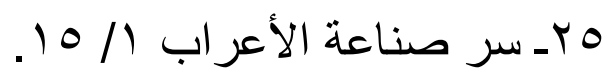

דr ـ ثمار الصناعة في علم العربية مبـ.

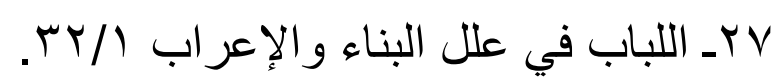

^ץ المصدر نفسه r/ / •.

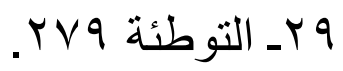

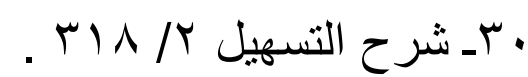

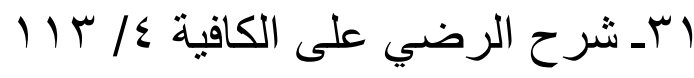

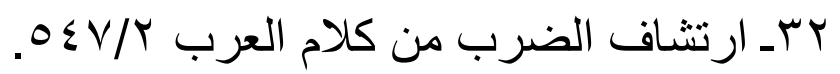

سبـ ينظر حروف المعاني 1 ـــ كتاب الأزهية في علم الحروف ^ץ.

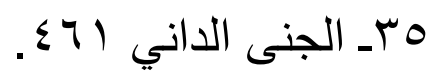
7rـ مغني اللبيب 10/1. .

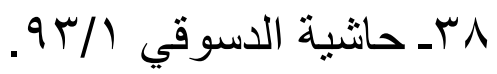
qrـ مغني اللبيب •عـ النحو الوافي /77.

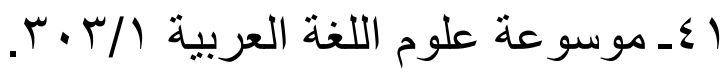




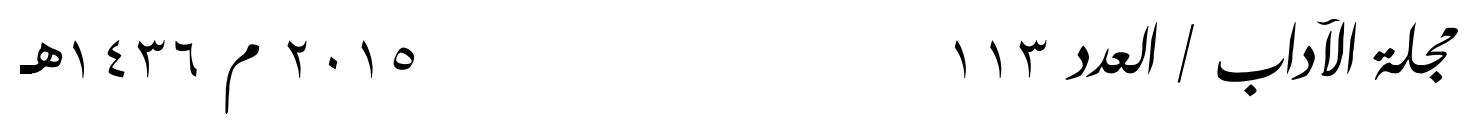

r كـ في التطبيق النحوي سا.

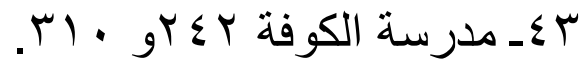

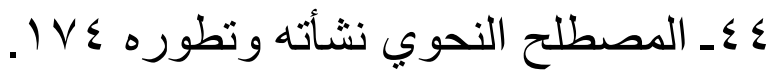

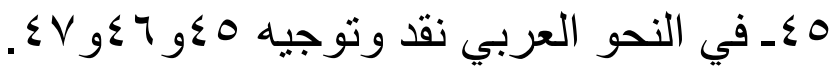

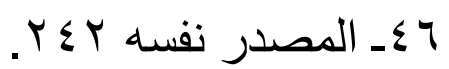

V _ ينظر اللغة العربية مبناها ومعناها Yor

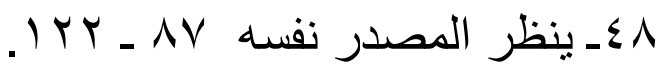

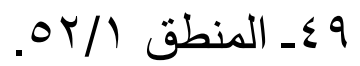

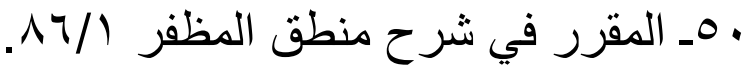

10 الألفاظ المستعملة في المنطق بـ ــ

الاول نشأة النحو العربي في ضوء كتاب سيبويه ، مجلة المجمع العلمي الأردني العدد

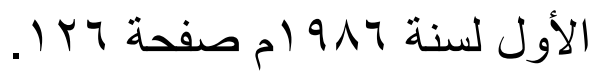
بهـ مفاتيح العلوم A^. كــ النحو الوافي آT/7.

00ـ الإشار ات و التنبيهات / / ع 1.

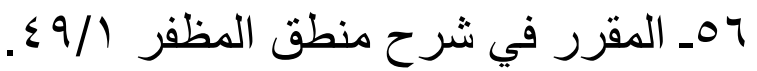
. OV هـ المصدر نفسه 9 ؟.

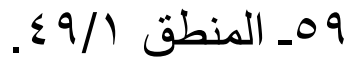
• جـ أي السيد كمال الحيدري . آـ المقرر في شرح منطق المظفر / AT. 
با بـ المصدر نفسه

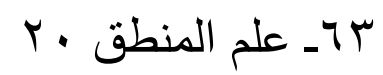

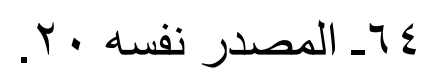

VY الخلاف النحوي في الأدوات ؟ ب. وينظر الحلل في إصلاح الخلل TV - ينظر معاني القرآن للكسائي

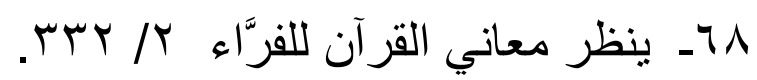

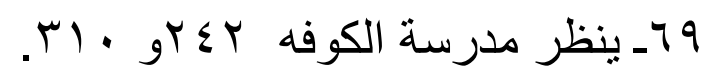

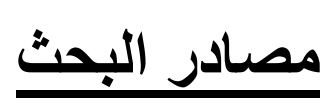

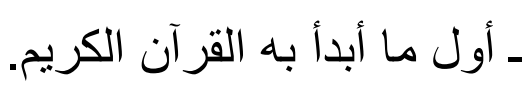

ـ الاجتهاد النَّحوي في ضوء علم الأصول ـ ر رائد عبد الله حمد السامر ائي ـ إطروحة

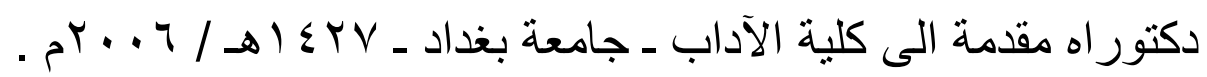

ـ الإتقان في علوم القرآن - جلال الدين عبد الرحمن السيوطي (ت الاوهـ ) ـ عالم

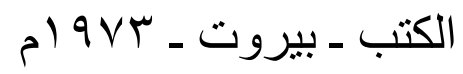

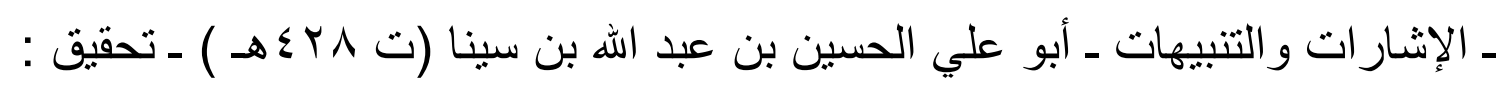

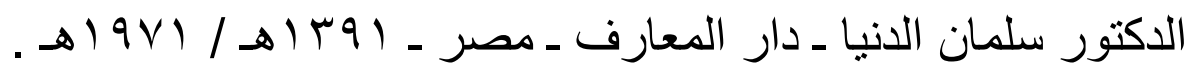

ـ الأصول في النحو ـ أبو بكر بن السرَّاج (تح آهـ) ـ تحقيق : الدكتور عبد الحسين

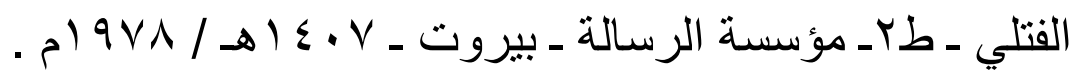

ـ التطبيق النحوي ـ الدكتور عبده الراجحي ـ دار النهضة العربية ـ بيروت ـ . $911 / 1 \leq 1$

ـ تكوين العقل العربي ـ الدكتور محمد عابد الجابري ـ طا ـ دار الطليعة للطباعة

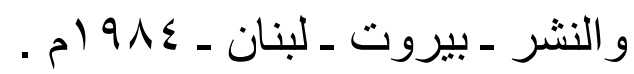

التوطئة ـ أبو علي الثلوبين (ت عـا 7هـ) تحقيق : الدكتور يوسف أحمد مطوع . 1911 
ـ ثمار صناعة الإعراب ـ للجليس الدنيوري (ت.9 §هـ ) تحقيق ودراسة الدكتور

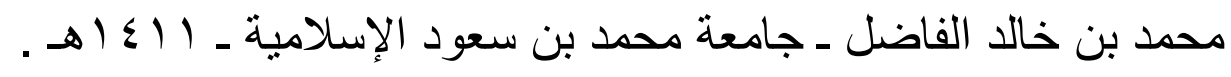

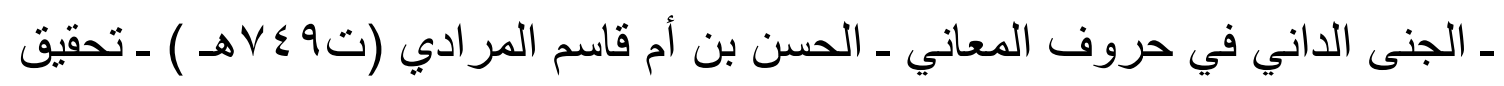

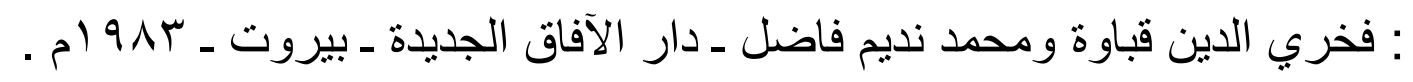

ـ حاثية الدسوفي على الثرح الكبير ـ محمد بن عرفة الدسوقي (ت • ب ا اهـ) تحقيق :

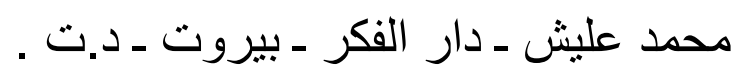

ـ حروف المعاني ـ أبو القاسم عبد الرحمن بن اسحق الزجاجي (ت •ـ ـاهـ ) ـ تحقيق:

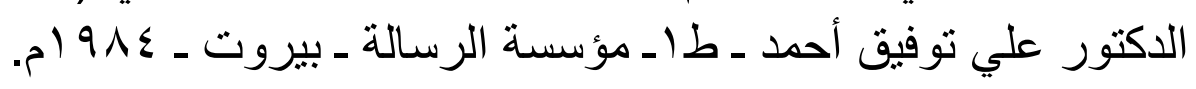

ـ الحلل في إصلاح الخلل من كتاب الجمل ـ أبو محمد عبد الله بن محمد بن السيد

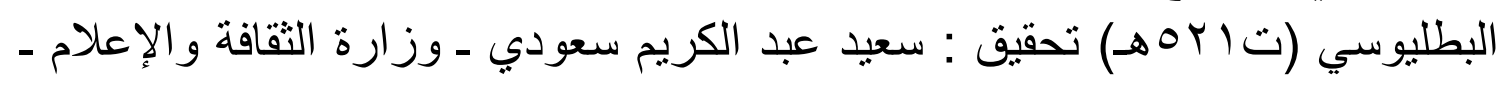

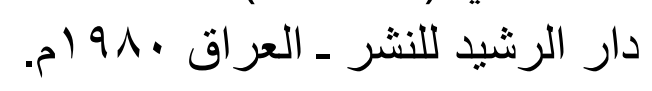

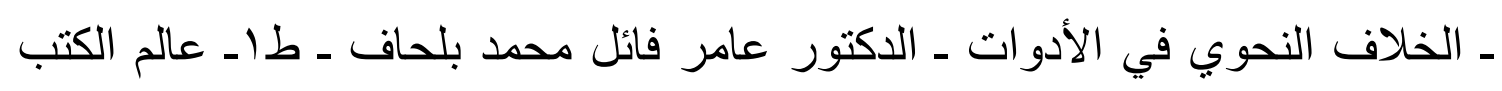

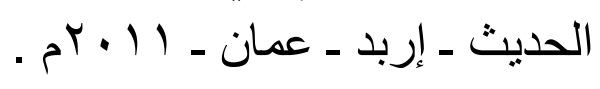

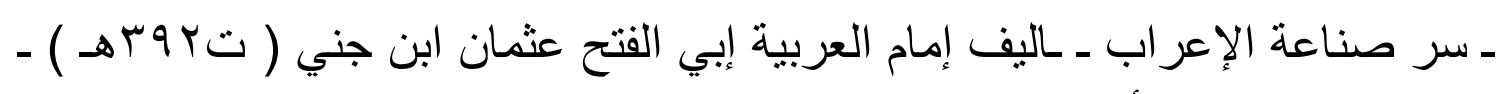

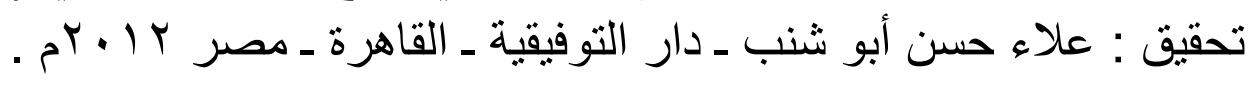

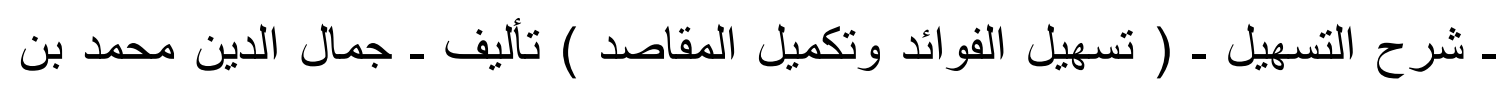

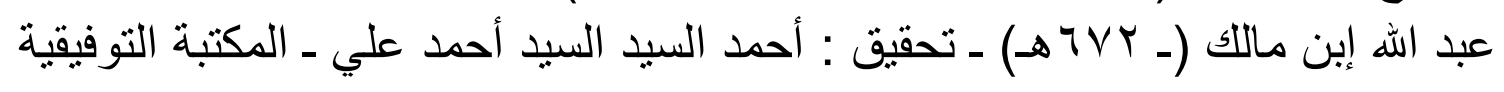

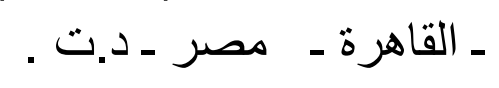

ـ شرح كافية ابن الحاجب ـ تأليف ـ رضي الدين محمد بن الحسن الاستربادي

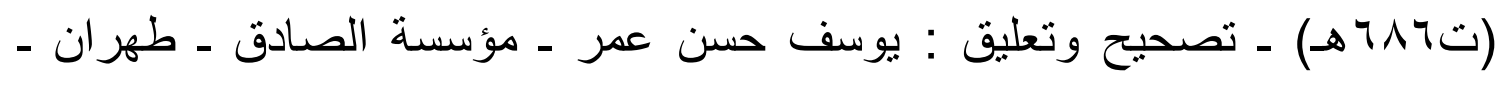

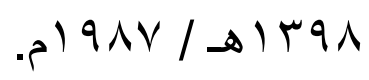

ـ شرح كتاب سيبويه ـ تأليف أبي سعيد السيرافي الحسن بن عبد الله المزربان

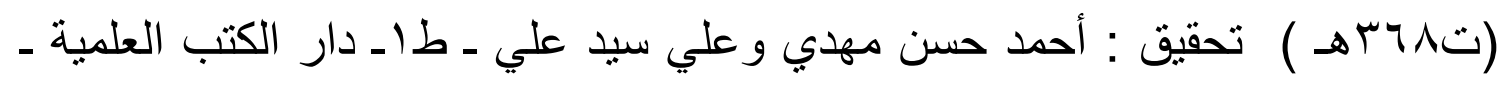

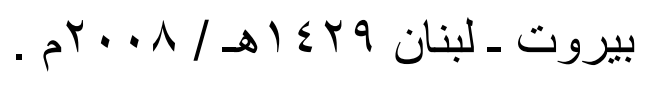

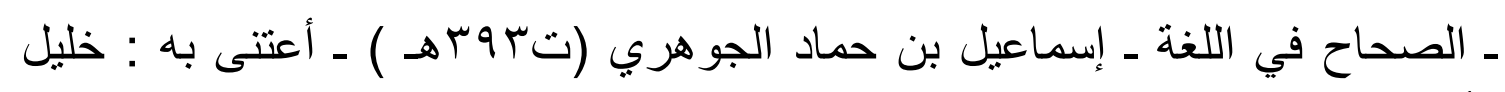

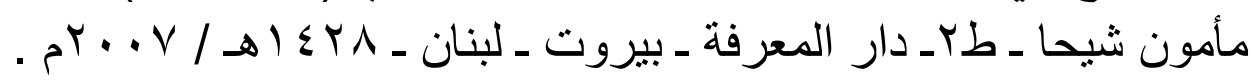


ـ علم المنطق ـ الدكتور محمد رمضـان عبد الله ـ طبع على نفقة جامعة بغداد ـ وزارة

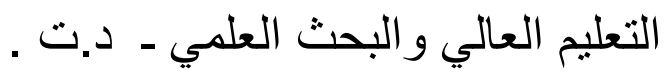

ـ عيون الأنباء في طبقات الأطباء ـ موفق الدين أبو العباس أحمد بن القاسم الخزرجي

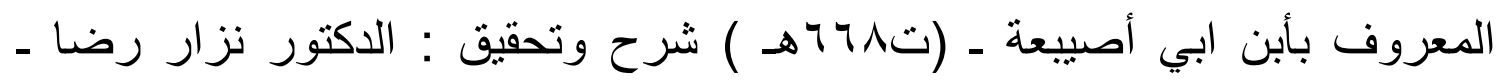

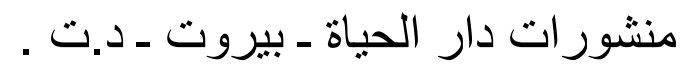

ـ في النحو العربي نقد وتوجيه ـ الدكتور مهدي المخزومي ـ طبـ دار الشؤون الثقافية

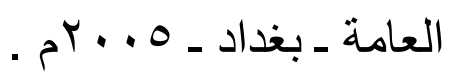

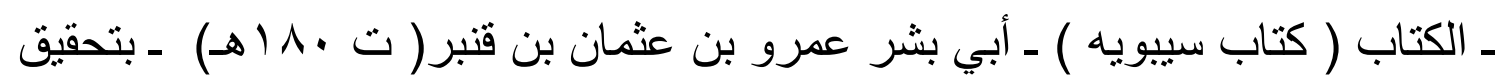

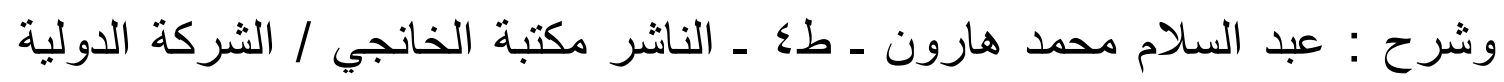

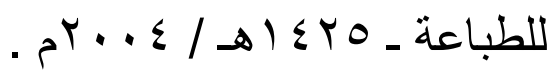

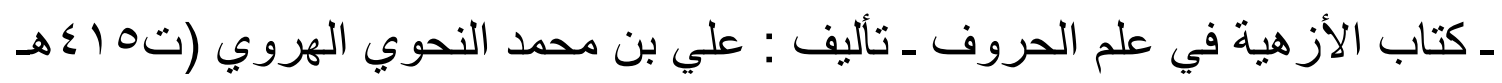

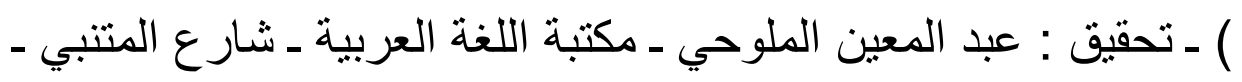

ـ كتاب العنوان في القراءات السبع ـ لأبي طاهر إسماعيل بن خلف المقرئ الأنصاري

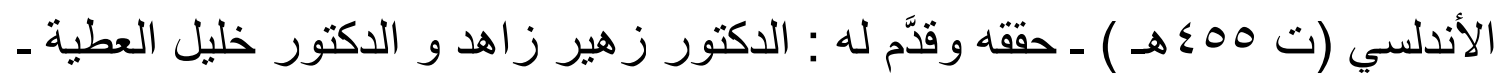

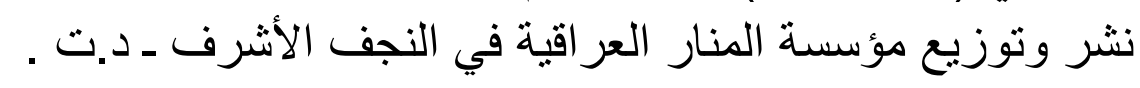
ـ كتاب المصوتات الوترية ذات الوتر الواحد الى ذات الى العشرة ـ أبو يوسف يعقوب

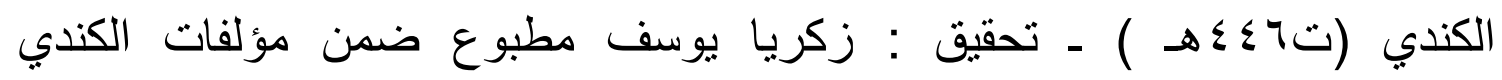

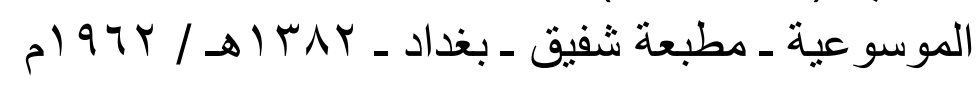

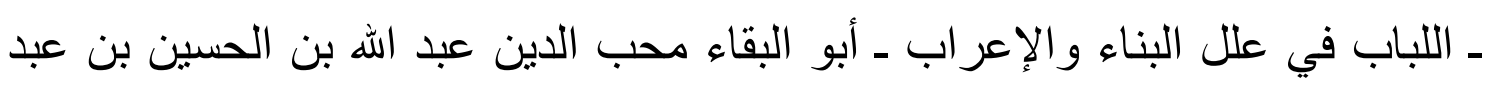

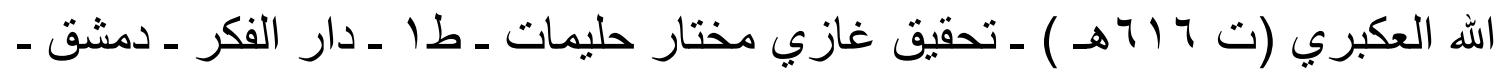
. ) 990

ـ اللغة العربية مبناها ومعناها ـ الدكتور تمام حسان ـ طبـ الهيئة المصرية العامة ـ . م) $9 \vee 9$

ـ مؤلفات الفار ابي ـ الدكتور حسين على محفوظ والدكتور جعفر آل ياسين ــ وزارة

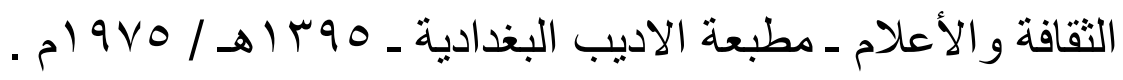




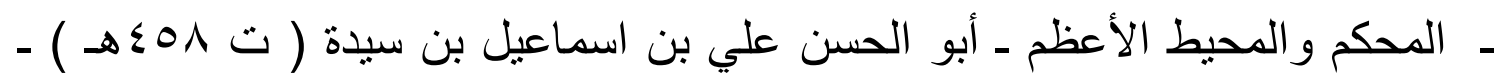

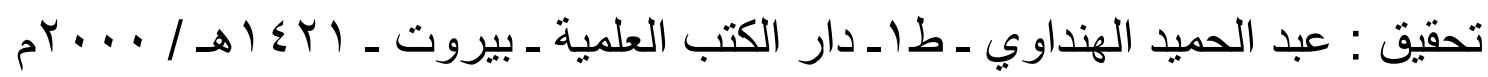

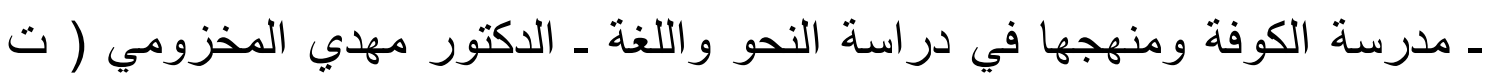

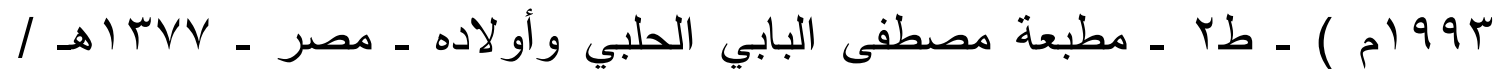
. 1901

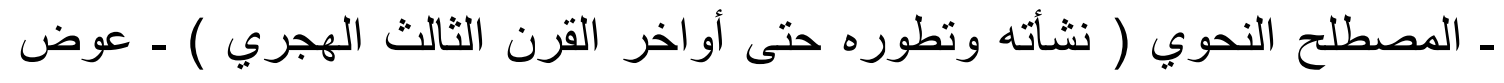

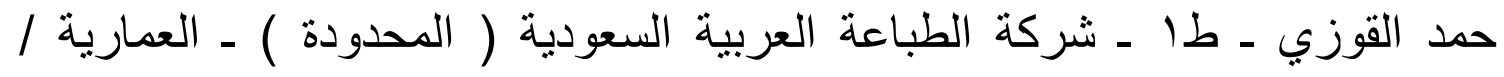

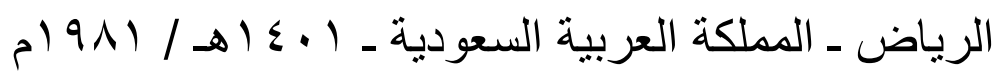

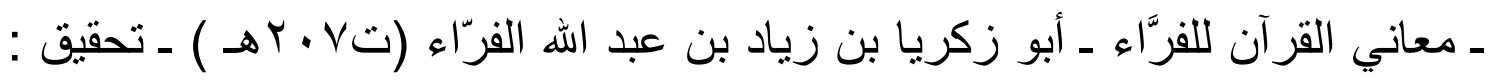

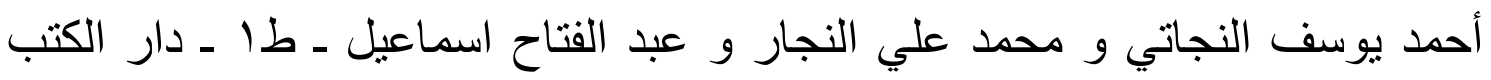

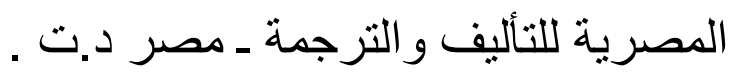

ـ معاني القرآن للكسائي ـ علي بن حمزة الكسائي (ت9 1/ اهـ ) أعاد بناءه وقدم لله

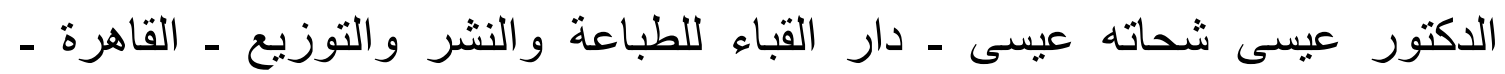
. م 991

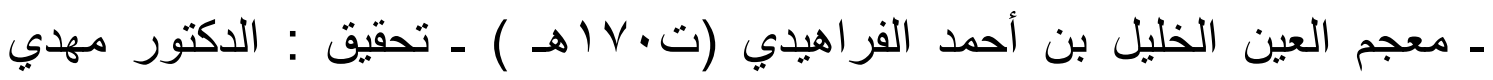

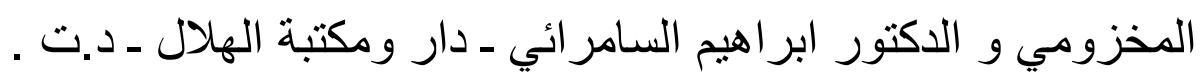

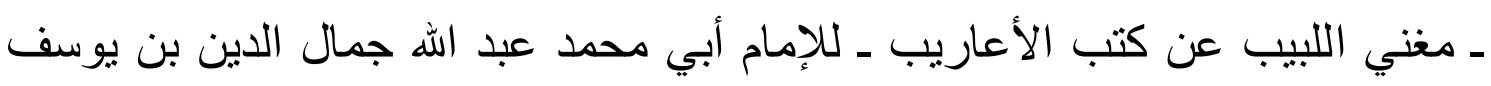

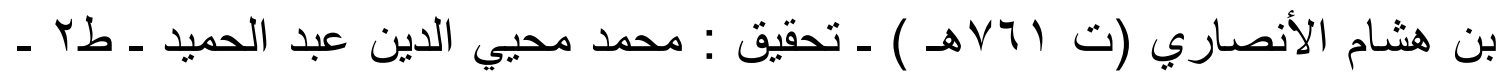

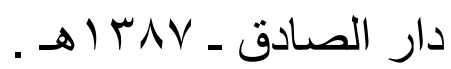

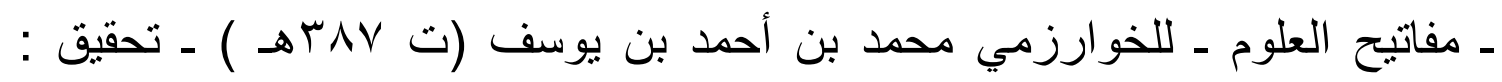

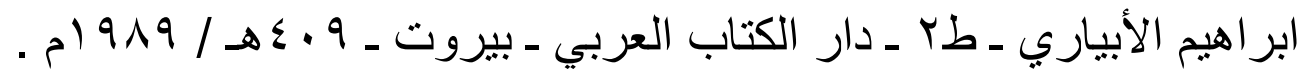

ـ المقتضب ـ محمد بن يزيد عبد الأكبر المبرد (ت بم بهـ ) ـ تحقيق : محمد عبد

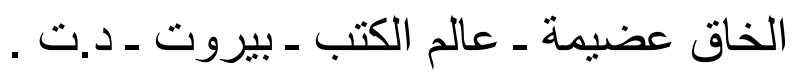

ـ مقدمة في النحو ـ تأليف خلف الأحمر خلف بن حيان الأحمر البصري (ت. ـ (1هـ )

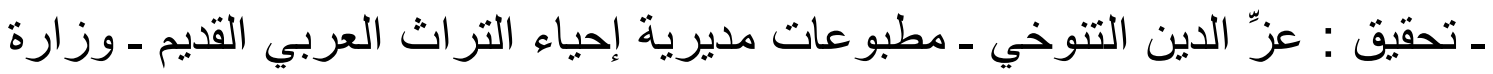

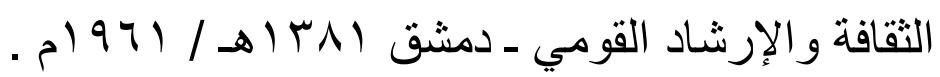




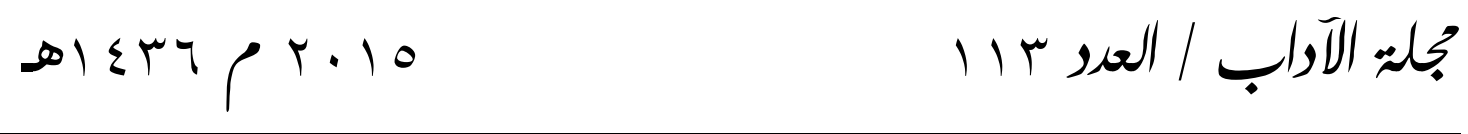

ـ الدقرر بشرح منطق المظفر ـ السيد كمال الحيدري ـ طا ـ مطبعة سليمان زاده ـ

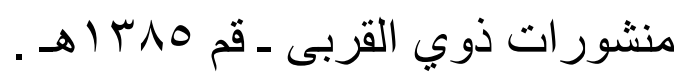

ـ المنطق ـ العلامة محمد رضا المظفر ـ طال اله ـ مطبعة سرور ـ الناشر إسماعيليان ـ

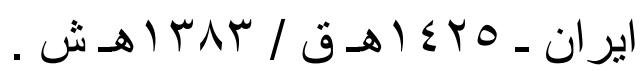

ـ موسوعة علوم اللغة العربية ـ إعداد الدكتور اميل بديع يعقوب ـ طا ـ دار الكتب

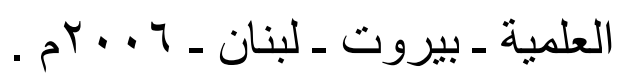

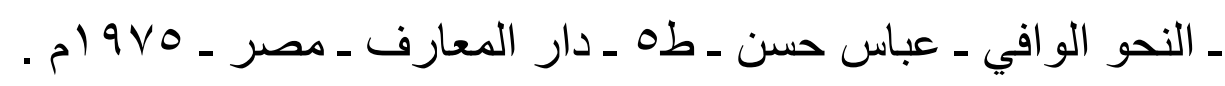

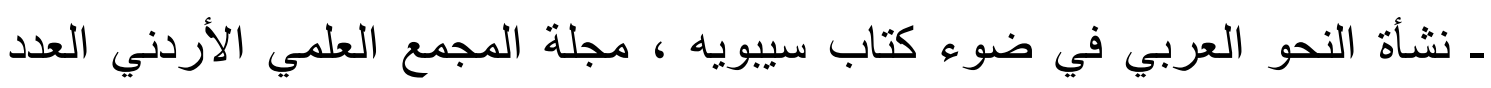

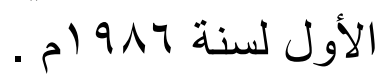

